\title{
Öğretmenlerin Tasarım Odaklı Düşünmeye İlişkin Bilişsel Yapıları ve Kavramsal Değişimleri
}

\author{
Derya GIRGIN \\ Çanakkale Onsekiz Mart Üniversitesi, Eğitim Fakültesi, Özel Eğitim Bölümü, Çanakkale \\ deryagirgin@comu.edu.tr, \\ ORCID ID: https://orcid.org/0000-0002-6114-7925
}

\begin{tabular}{lrr} 
Araştırma Makalesi & DOI: $10.31592 /$ aeusbed.578729 \\
\hline Geliş Tarihi: 17.06 .2019 & Revize Tarihi: 17.10 .2019 & Kabul Tarihi: 31.10 .2019
\end{tabular}

\section{Atıf Bilgisi}

Girgin, D. (2019). Öğretmenlerin tasarım odaklı düşünmeye ilişkin bilișsel yapıları ve kavramsal değişimleri. Ahi Evran Üniversitesi Sosyal Bilimler Enstitüsü Dergisi, 5(2), 459-482.

\section{ÖZ}

$\mathrm{Bu}$ araştırmanın amacı öğretmenlerin tasarım odaklı düşünme eğitimine ilişkin bilişsel yapılarını ve kavramsal değişimlerini ortaya koymaktır. Bu amaç çerçevesinde araştırma tarama modelinde gerçekleştirilmiştir. Araştırma, 2018-2019 eğitim-öğretim yılı güz döneminde Rize il merkezinde ilkokul, ortaokul ve liselerde görev yapan farklı branşlardaki 32 (16 erkek, 16 kadın) öğretmen ile gerçekleştirilmiştir. Veri toplama aracı olarak kelime ilişkilendirme testi kullanılmıştır. Araştrımada öğretmenlere, 3 gün boyunca (günde 4 saat) olmak üzere toplam 12 saat tasarım odaklı düşünme eğitimi verilmiş, bu eğitimin öncesinde ve sonrasında kelime ilişkilendirme testi uygulanmıştır. Öğretmenlerin bilişsel yapıları belirlenmiş, kavram yanılgıları ortaya konmuş ve kavramsal değişim süreçleri irdelenmiştir. Öğretmenlerin kelime ilişkilendirme testine ilişkin ön test ve son test verileri karşılaştırılmıştır. Son test verilerinde anahtar kavrama yönelik üretilen kelime sayısı artış göstermiştir. Araştırmada öğretmenlerin anahtar kavram ile ilgili kurdukları cümleler incelendiğinde kavramsal değişim noktasında olumlu anlamda değişim gösterdiği, son testte anahtar kavramla ilgili bilimsel bilgi içeren cümlelerin sayısında artış olduğu, bilimsel olmayan ve yüzeysel bilgi içeren cümlelerin sayısında da azalma olduğu görülmüştür. Kavram yanılgılarının sayısı da ön testten son testte doğru azalmaktadır. Araştırma sonucunda kavramsal yapıyı ortaya koymada ve kavramsal değişimi belirlemede uygulanabilecek önemli bir yaklaşım olarak kelime ilişkilendirme testlerinin kullanılabilirliğine ilişkin önerilere yer verilmiştir.

Anahtar Kelimeler: Bilişsel yapı, kavramsal değişim, kelime ilişkilendirme testi, tasarım odaklı düşünme.

\section{The Cognitive Structure of Teachers Concerning Design-Based Thinking and Their Conceptual Change}

\begin{abstract}
The aim of this study is to reveal the cognitive structures and conceptual changes of teachers regarding design- based thinking education. For this purpose, the research was carried out in the screening model. The research is conducted in the 2018-2019 autumn term, in the centre of Rize province with the participants of 32 teachers (16 male, 16 female) who was working in different fields of study at the primary, middle, and high schools in the region. Word association test (WAT) is used for the data collection. In the study, 12 hours of design-based thinking training was given to the teachers for 3 days ( 4 hours per day) and word association test was applied before and after this training. Cognitive structures of teachers were determined, misconceptions were revealed and conceptual change processes were examined. Pre-test and post-test data of the teachers' word association test were compared. The number of words produced for the key concept in the last test data increased.In the study when teachers' sentences concerning the key concept were studied, there was a positive transformation in relation to conceptual change and the number of sentences with the scientific content concerning the key concept increased in the post-test, while non-scientific sentences with superficial information decreased. The number of misconceptions also decreased from pre-test to post-test. The study results include suggestions in applying the word association test as an important approach for revealing the cognitive structure and determining conceptual change.

Keywords: Cognitive structure, conceptual change, word association test, design-based thinking.
\end{abstract}

\section{Giriş}

Tasarım odaklı düşünme, öğrencilerin yaratıcı güvenini geliştirmeye odaklanan bir öğrenme yaklaşımıdır. Empati geliştirme, eyleme yönelik önyargıları teşvik etme, düşünmeyi yönlendirme, meta bilişsel farkındalık geliştirme, aktif olma, problem çözme ve kişinin hayal gücünü kullanma gibi birçok unsuru içinde barındırır. Tasarım odaklı düşünme yoluyla öğretmenlerin pedagojik repertuarının genişletilmesi böylelikle üretim faaliyetlerinin artırılması söz konusudur. Tasarım odaklı 
düşünme süreci bir problemin tanımlanması ile başlar, araştırmayı ve sıklıkla birbiriyle rekabet halinde görünen önceliklerin sıralamasını içerir, çoklu çözümlerin uygulanabilirliğini prototiplerle test eder ve nesnelerin sosyal açıdan değerlendirilmesiyle son bulur (Davis, 1998).

Bireylerin yaşamlarındaki en önemli unsurun yaratıcı problem çözme olduğunu göz önüne aldığımızda tasarım odaklı düşünme karmaşık sorunlara yaratıcı çözüm bulma konusunda oldukça işlevsel bir yaklaşımdır (Carroll, Goldman, Britos, Koh, Royalty ve Hornstein, 2010; Vande Zande, Warnock, Nikoomanesh ve Van Dexter, 2014). Tasarım düşüncesi bireylerin eleştirel düşünmelerini, sosyal gelişimlerini, takım çalışma becerilerini destekleyerek öğrencilerin akademik anlamda da performansını destekler. Öğrencilerin anlama, tanımlama ve analiz sürecine katkıda bulunarak, onların akademik performansinı arttırır (Carroll vd., 2010; Vande Zande vd., 2014; Watson, 2015).

Tasarım odaklı düşünme işbirliğine dayalı, problem çözme yöntemlerini kullanan insan merkezli bir yaklaşımdır. Tasarım düşüncesinde sorgulama-keşif yaklaşımıyla bireylerin problem çözme veya yaratıcı yetenekleri, performansları arttırılabilir (Treffinger, 1980). Tasarım düşüncesi bireye belirli beceriler ve bilgiler kazandırması için firsat yaratmaktadır (Bootcamp Bootleg D.School, 2011). Bir tasarım düşünürü olmak; karmaşık problemleri çözmek bilinçli kararlar almaktır (Löwgren ve Stolterman, 2004). Eğitim bağlamında, pedagojik yaklaşımlarla tasarım düşünme becerileri öğrenilebilir. Sınıfta probleme dayalı öğrenme, proje tabanlı öğrenme ve sorgulamaya dayalı öğrenme içeren aktiviteler yapılabilir. Tasarım odaklı düşünme temelinde oluşturulan öğretim programlarında öğrencilerin işbirliği, problem çözme ve empati dahil belli beceriler kazanması beklenir (Carroll vd., 2010; Dukes ve Koch, 2012; Lee ve Bichard, 2008).

Brown (2008), tasarım odaklı düşünmede çizim düşüncesini vurgular. Bu süreçte empati, bütünleştirici düşünme, işbirliği ile ürün geliştirme stratejini merkeze alır. Tasarım düşüncesini kullanarak tasarımcının duyarlılık ve eşleştirme yöntemleri ile insanların ihtiyaçları nedir, teknolojik olarak ne uygulanabilir, nasıl uygulanabilir sorularına yanıt arar. Martin (2009) ise tasarım düşüncesinde yaratıcı düşünmeye odaklanır. Vaka çalışmaları üzerinden süreç odaklı olarak var olan zorluklar, kabul edilen açıklamalar, üretilen fikirler ve olası yeni çözümleri merkeze alır. Bu bağlamda Apple, IBM gibi şirketlerin tasarım düşüncesi ile öncesi ve sonrasında gerçekleştirdiklerini ortaya koyar. $\mathrm{Bu}$ şirketler diğerlerine göre daha hızlı büyüme ve başarı grafikleri gösterirler. Çünkü ürün ve hizmet yaratmada kullanıcı odaklı bir yaklaşım benimserler. Meinel ve Leifer (2011) tasarım düşüncesini insanı merkeze alarak iş ve teknolojiyi bütünleştirerek sorunları irdeleme ve çözme olarak ifade eder. Tasarım odaklı düşünmenin insan merkezli bir yaklaşım olduğunu, sosyal bilimler, mühendislik vb. gibi birçok disiplinin, alanın birleştirilerek harmanlanması ile oluştuğunu belirtir. İnsan odaklı olarak çok disiplinli bir yapıda işbirliği içerisinde interaktif iyileştirmeleri gerçekleştirdiğini, sezgisel olarak tasarım düşünme süreci uygulandığını ortaya koyar. Bu çerçevede tasarım odaklı düşünme yapısına ilişkin dört temel kategori alanı karşımıza çıkmaktadır. Tasarım odaklı düşünmeye yönelik dört temel kategori Brown'a (2008) şu şekilde ortaya konmuştur:

-Insan odakl1 tasarımdir.

•Bütünleştirici düşünmeyi sağlar.

- Tasarım yönetimi süreç aşamalarını içerir.

-Öğretim sürecinde bir strateji olarak kullanılır.

Tasarım odaklı düşünmenin en tanınmış ve öne çıkan kategori alanı insan merkezli tasarım öğesidir. İnsan odaklı tasarım, insanlara veya müşterilere ve onların ihtiyaçlarına odaklanmak olarak tanımlanır. Nussbaum (2009) bu süreçleri şöyle özetlemektedir: Gözlem, beyin firtınası, hızlı prototipleme, test etme ve uygulama. Bunlarda kullanılan tasarım düşüncesinin temel ilkeleri bireyler hakkında derinlemesine bir anlayış geliştirmektir. Bu anlayış süreci saha araştırması empatik düşünme ile başlar; işbirliği içinde ortak çalışmalarla gerçek dünyada gözlemsel uygulamalarla devam eder. Tasarım düşüncesi multidisipliner ekipler oluşturarak radikal değerlendirmeye imkân sağlar. Uygulamalı deneyler sayesinde görselleştirme yoluyla öğrenmeyi hızlandırarak, oluşturulan prototiplerin denemesini sağlar. Tasarım düşüncesinin vurguladığı en önemli nokta uygulamalı denemeler ile bireylerin hızlı düşünüp, hızlı karar vererek, başarısızlığa uğradıklarında tekrar deneme 
yapmaları ile öğrenmenin gerçekleşebileceğini vurgulamasıdır. Bu yüzden temel ilkesi hızlı düşün, hızlı yanıl, düzelt şeklindedir.

Tasarım odaklı düşünme yaklaşımı insan merkezli bir tasarım olmanın yanı sıra doğrusal olmayan yinelemeli işlemlerde içerir. Sorunun tanımlanması, ardından kullanıcının ve tasarım alanının keşfedilmesi, ortaya çıkarılması, beyin fırtınası, daha sonra test edilen prototipler oluşturma gibi bir dizi süreci içerir. Lockwood (2009) tasarım düşüncesinin, problemlerin çözülmesinde bir yaklaşım olarak değil de bir yöntem olarak görülmesi gerektiğini vurgulamıştır. Liedtka'ya (2011) göre tasarım düşüncesi sürekli olarak yeniden tasarlanması gereken bir süreçtir. Simon (1996) tasarım düşüncesini, mevcut koşulların tercih edilenlere dönüştürülmesi olarak tanımlamıştır. Pink'e (2005) göre, tasarım düşüncesi, problem çözme için gerekli olan zihin çerçevesidir. Martin (2012) tasarım düşüncesini hem analitik hem de sezgisel düşünmeyi içeren yapı olarak tanımlar.

\section{Okullarda Tasarım Düşüncesi}

Okullar sürekli öğrenci öğrenmesini ve donanımını geliştirmenin yeni yollarını aramaktadır. Öğrencilerin 21. yüzyılın ortaya koyduğu taleplerle başa çıkmalarını sağlayacak becerilere sahip olması gerekmektedir. $\mathrm{Bu}$ bağlamda tasarım odaklı düşünme öğrenciler arasında yaratıcılığı artıracağından ve onların inovasyon sürecini anlamalarına yardımcı olacağından umut verici bir yaklaşım olarak alan yazında vurgunlanmaktadır (Brown, 2008; Martin, 2009). Tasarım düşüncesi öğrenme için yeni bir iç görü oluşturur (Pendleton- Jullian ve Brown, 2008) Öğretim sürecinde öğretmenler birincil tasarımcılardır çünkü sınıfta öğrencilerinin öğrenim deneyimlerini tasarlarlar (Kirschner, 2015). Öğretmenler öğrencileri için uygun araçları seçmeli ve oluşturmalıdır. Öğretmenler amaca hizmet edecek hedefleri belirlemeli ve öğrencilerin yaratıcı şekilde sorunları yeniden çerçevelendirmelerine, çözmelerine yardımcı olmalıdır. Öğretmenler için tasarım odaklı düşünme, güçlü öğrenme için deneyim yaratmak demektir (Kali, McKenney ve Sagy, 2015). Bunlara ek olarak tasarım odaklı düşünme, sınıf içerisinde beklenmeyen ihtiyaçlara cevap verme firsatları da sunar (Svihla, Reeve, Sagy ve Kali, 2015; Vaughn ve Parsons, 2013).

Tasarım düşüncesi, soyut bir problem için somut önerilere imkân yaratan insan merkezli süreçtir (Scheer, Noweski ve Meinel, 2012). Sosyal öğrenmeyi teşvik eder. İnsanların ihtiyaçlarını karşılamak için problem çözmeyi kullanır. Odak noktası insanlar ve onların var olan soyut problemlerden ziyade çözüm gerektiren açık problemleridir. Anderson'a (2012) göre tasarım düşünme becerileri gelecek için oldukça önemlidir. Okullar kendi öğretim programlarını tasarlama, farklı deneyimleri anlama için bu yaklaşıma yönelmektedir (Barseghian, 2010). Tasarım düşüncesi ile gerçekleştirilen derslerin genel öğrenci açısından önemli gelişmeler sağladığı yapilan çalışmalarla ortaya konmuştur (Philloton ve Miller, 2011). Başka bir örnekte Krieger (2010), Hindistan ve Meksika'daki okullarda tasarım düşüncesini başarıyla uygulamaya koymuştur. Bu okullar, tasarım düşüncesini farklı bilim alanlarında belirli konularda kullanmışlardır (Kolodner, Camp, Crismond, Fasse, Gray, Holbrook ve Ryan, 2003). Matematik alanında (Goldman, Knudsen ve Latvala, 1998), teknoloji alanında (Kafai ve Resnick, 1996) ve dini çalışmalarda (Tan ve Wong, 2012) tasarım odaklı düşünme yaklaşımını öğretim sürecinde kullanmıştır. Bu çalışmalarda tasarım odaklı düşünme, öğrencilerin yaratıcılık ve problem çözme gibi becerilerini geliştirme potansiyeline imkân sağlamıştır. Ayrıca öğrencilerin bilişsel ve sosyal becerilerini geliştirmelerine de yardımcı olmuştur (Todd, 1999).

\section{Tasarım Odaklı Düşünme Sürecinin Aşamaları}

Bir çözüm geliştirmeden önce tüm paydaşlara ilişkin beyin firtınası yapılırken yaratıc1lığa vurgu yapılır. Tasarım düşünme süreci üç soru ile başlar (Brown, 2009; Rodgers ve Winton, 2010):

-Arzu edilebilirlik: İnsanlara ne mantıklı geliyor, insanlar ne arıyor, insanlar için ne gerekli? Soruları sorulur. Bu çerçevede bir çözüm veya bir dizi çözüm ortaya konur.

•Fizibilite: İşlevsel olarak mümkün olan nedir? Karmaşık soruna ilişkin çözüm ortaya konabilir. Ama önemli olan çözümün işlevsel olarak hayata geçirilebilmesidir. 
•Canlılık: Çözümün sürdürülebilir olma olasılığı nedir? Sorusuna yanıt aranır. Buradaki anlam soruna ilişkin çözümün süreklilik arz etmesidir.

Bu üç soruyu göz önünde bulundurduktan sonra, tasarım düşüncesi çok aşamalı bir yaklaşım kullanır. Bunlar; beyin firtınası, prototip geliştirme, test, revizyon ve tekrar testtir (Plattner, 2010).Tasarım odaklı düşünme süreci aşamalarını, Brown (2008) ise şu şekilde belirtmiştir:

1.Empati kurmak: Farklı bakış açısı kazanmayı sağlar.

2.Tanımlamak: Farklı bakış açıları ile durumu anladıktan sonra, net bir açıklama taslağı oluşturulmasını sağlar. Sorun hakkında tüm paydaşlarla görüşme yapılıp, sorunun tanımlanması gerçekleştirilir.

3.Fikir üretmek: Tanımlanan soruna ilişkin geniş potansiyel çözümlerin oluşturulmasıdır. $\mathrm{Bu}$ aşamada, değerlendirme yapılmaksızın tüm olası fikirler önerilebilir.

4.Prototip geliştirmek: Soruna ilişkin oluşturulan daha büyük fikir havuzu ile fikrin hayat bulması aşamasıdır. Geliştirilen prototip sorun alanına bağlı olarak bir skeç, sunum olabileceği gibi bir diyagramda olabilir.

5.Test etmek: Yazılı veya tasarlanmış çözümlerin paydaşlarla paylaşılması aşamasıdır. Yapıcı geribildirim aldıktan sonra neyin iyi olduğu, neyin olmadığı ve neyin geliştirilebilir olduğu bu kısımda ortaya konur. $\mathrm{Bu}$ aşamada tanımlama aşamasına, fikir üretme ya da prototip geliştirme aşamalarına da geri dönülebilir.

Bilişsel yapının ölçülmesinde ve kavramlar arasındaki ilişkilerin belirlenmesinde, kelime ilişkilendirme testi sıklıkla kullanılan bir tekniktir (Bahar, Nartgün, Durmuş ve Bıçak, 2010). Kelime ilişkilendirme testleri alan yazında pek çok çalışmada kavram yanılgılarını tespit etme, verilen konuya yönelik bilişsel yapıları ortaya koyma, bireylerin kavramsal değişimlerini gözlemleme, belli bir konu ile ilgili algıyı belirlemek amacıyla kullanılmıştır (Bahar, Johnstone ve Sutcliffe, 1999; Bahar ve Tongaç, 2009; Ercan, Taşdere ve Ercan, 2010; Kaya ve Akış, 2015; Nakiboğlu, 2008; Özsevgeç ve Türkmen, 2014; Taşdere, Özata-Yücel ve Özkan, 2015; Yiğit ve Atabek-Yiğit, 2016). Bu araştırmalar incelendiğinde, genellikle öğrencilerin fen bilimleri ya da sosyal bilimler alanındaki kavramlara ilişkin bilişsel yapılarını belirlemek amacıyla kelime ilişkilendirme testlerinin kullanıldığı görülmektedir. Çok azda olsa farklı branşlarda özellikle fen bilimleri dışında sosyal bilimlerde kelime ilişkilendirme testinin kullanıldığı çalışmalar mevcuttur (Bahar ve Kılıç, 2001; Çiftçi, 2009; Deveci, Köse Çengelci ve Bayır Gürdoğan, 2014; Kaldırım, 2005; Tuncel ve Ayva, 2010). Aynı zamanda az sayıda da olsada öğretmen adaylarının bilişsel yapılarını ve kavramsal değişimlerini belirlemeye yönelik kelime ilişkilendirme çalışmaları son zamanlarda karşımıza çıkmaktadır (Atabek-Yiğit ve Balkan-Kıyıcı, 2019; Çetin ve Ünsal, 2019; Gürkan, 2019; Karip, 2019; Kaya ve Bozyiğit, 2018).

Öğretmenlerin bilişsel yapılarını ortaya koymaya yönelik ya da kavramsal değişimlerinin gözlenmesine ilişkin alan yazında kelime ilişkilendirme testi ile ilgili araştırmaların sayısı sınırldır. $\mathrm{Bu}$ araştırmanın amacı, alternatif bir ölçme ve değerlendirme tekniği olan Kelime İlişkilendirme Testi (KIT) aracılığı ile farklı branşlardaki öğretmenlerin tasarım odaklı düşünmeye yönelik bilişsel yapılarını ve kavramsal değişimlerini ortaya koymaktır. Kelime ilişkilendirme testleri bilişsel yapıyı ve bu yapıdaki kavramlar arasındaki bağları, kavramlar arası ilişkilerin yeterli olup olmadığını veya anlamlı olup olmadığını ortaya koyan alternatif ölçme değerlendirme tekniklerinden birisidir (Bahar, Alex, Johnstone ve Sutcliffe, 1999). Bu bağlamda, öğretmenlerin eğitimde uygulanan yeni bir yaklaşım olan tasarım odaklı düşünmeye ilişkin bilgi organizasyonlarının belirlenmesinin ve nasıl yapılandırıldığının ortaya konmasının alana katkı sağlayacağı düşünülmektedir.

Kelime ilişkilendirme testleri; bireylerin bilişsel yapısını ve bu yapıdaki kavramlar arası bağları, uzun dönemli hafızadaki kavramlar ile ilişkilendirmelerinin anlamlı olup olmadığının tespit edilebilmesi amacı ile kullanılan bir tekniktir. Bu teknikte, belli bir süre içerisinde (yaş grubuna göre genellikle 30-60 sn) verilen konu ile ilgili bir anahtar kavramın çağrıştırdığı kelimeleri cevap olarak verilmesi istenir. Bireylerin anahtar kelimelere verdikleri cevapların sayısına ve çeşidine göre onların konuyu tam olarak anlayıp anlamadıkları yorumlanabilir. Böylelikle bireylerin kelime ilişkilendirmesi yaptıkları konudaki kavramlar arasındaki ilişki belirlenebilir. Bir ölçme aracı ya da bir tanılama aracı 
olarak kullanılabilen kelime ilişkilendirme testleri; uygulama başında ön test, sonunda da son test olarak uygulanabilir. Uygulama tamamlandığında her iki testin sonuçları birbiriyle karşılaştırılır. Bu karşılaştırma ile kavram gelişimleri konusunda katılımcıların değişiklikleri izlenir (Bahar, Johnstone ve Sutcliffe, 1999).

Millî Eğitim Bakanlığı'nın (MEB) 2023 Eğitim Vizyon belgesinde tasarım odaklı düşünme yapısının "Tasarım-Beceri Atölyeleri” ismi ile ulusal standartlarının oluşturulup kurulması konusunda hedefi belirtilmektedir (MEB, 2018). Hedeflenen Tasarım-Beceri Atölyeleri ile öğrenilen bilgilerin yaşam becerisine dönüştürülmesi, çocukların yetenekleriyle ilişkilendirilmiş becerileri uygulama düzeyinde kazanabilmeleri sağlanacaktır. Alan yazında 2023 Eğitim Vizyonu kapsamında tasarımbeceri atölyeleri ile hedeflenen tasarım odaklı düşünme sürecinin öğretmenler tarafından nasıl algılandığını ortaya koyan bir çalışmaya rastlanmamıştır. Araştırma bu bağlamda tasarım odaklı düşünmeye yönelik öğretmenlerin hem bilişsel yapılarının tespit edilmesi ve kavramsal değişimlerinin ortaya konması açısından hem de bunun ortaya konmasında kelime ilişkilendirme testi kullanılması bakımından da alan yazına katkı sağlayacaktır. Bu çerçevede araştırmanın amacı kelime ilişkilendirme testi aracılığıyla öğretmenlerin tasarım odaklı düşünmeye yönelik bilişsel yapılarını ve kavramsal değişimlerini ortaya koymaktır.

\section{Yöntem}

$\mathrm{Bu}$ araştırma farklı branşlardaki öğretmenlerin tasarım odaklı düşünme eğitimine ilişkin bilişsel yapılarını ve kavramsal değişimlerini ortaya koymayı amaçlayarak tarama modelinde gerçekleştirilmiştir. Tarama modelleri, geçmişte ya da halen var olan bir durumu var olduğu şekliyle betimlemeyi amaçlayan araştırma yaklaşımlarıdır (Büyüköztürk, Çakmak, Akgün, Karadeniz ve Demirel 2014; Karasar, 2012). Bu modelde, araştırmacı herhangi bir şekilde araştırmaya müdahale etmemekte, bireyin ya da nesnelerin ait olduğu koşulları değiştirmemektedir. Tarama modelinde yapılan araştırmada, araştırmacı geniş bilgi içeren veri setine ulaşma imkânına sahiptir (Fraenkel ve Wallen, 2006). Çalışmada öğretmenlerin tasarım odaklı düşünmenin temel kavramlarına ilişkin bilişsel yapılarını ve kavramsal değişimlerini belirlemek amacıyla kelime ilişkilendirme testi kullanılmıştır.

\section{Çalışma Grubu}

Araştırmanın katılımcılarını 2018-2019 eğitim-öğretim yılında Rize ili merkezinde ilkokul, ortaokul ve liselerde görev yapan farklı branşlardaki 32 (16 erkek, 16 kadın) öğretmen oluşturmaktadır. Öğretmen seçiminde gönüllü, istekli olma, daha önce tasarım odaklı düşünme eğitimi kapsamında eğitim almamış olma, farklı branşlarda ve mesleki deneyimlerde olma gibi özellikler ön planda tutulmuştur. Bu bağlamda eğitime katılan ve uygulamayı gerçekleștiren öğretmenlerin mesleki kıdemi, mesleki deneyimleri ve branşları açısından katılımcılarda çeşitlilik sağlanmaya çalışılmıştır. Araştırmada gerçekleştirilen görüşmelere katılan öğretmenlerin demografik özelliklerine ilişkin bilgiler aşağıdaki tabloda verilmektedir.

Tablo 1

Çalışmaya Katılan Öğretmenlerin Kişisel Bilgileri

\begin{tabular}{llll} 
Katılımc1 & Cinsiyet & Mesleki Kıdem & Branş \\
\hline$\ddot{O ̈}_{1}$ & Kadın & $11-15$ yıl arası & Sinıf öğretmeni \\
$\ddot{O}_{2}$ & Erkek & $21-25$ yıl arası & Türkçe öğretmeni \\
Ö$_{3}$ & Kadın & $16-20$ yıl arası & Matematik öğretmeni \\
$\ddot{O}_{4}$ & Erkek & $16-20$ yıl arası & Fen Bilimleri öğretmeni \\
$\ddot{O}_{5}$ & Erkek & $6-10$ yıl arası & Türk Dili ve Edebiyatı öğretmeni \\
$\ddot{O}_{6}$ & Kadın & $11-15$ y1l arası & Müzik öğretmeni \\
$\ddot{O}_{7}$ & Kadın & $6-10$ yıl arası & Bilişim Teknolojileri öğretmeni \\
$\ddot{O}_{8}$ & Erkek & $21-25$ yıl arası & Din Kültürü ve Ahlak Bilgisi öğretmeni \\
$\ddot{O}_{9}$ & Kadın & $16-20$ y1l arası & Görsel Sanatlar öğretmeni \\
$\ddot{O}_{10}$ & Erkek & $21-25$ yıl arası & Sinıf öğretmeni
\end{tabular}




\begin{tabular}{|c|c|c|c|}
\hline$\ddot{O}_{11}$ & Erkek & $11-15$ yıl arası & Beden Eğitimi öğretmeni \\
\hline$\ddot{\mathrm{O}}_{12}$ & Kadın & $21-25$ y1l aras1 & Kimya öğretmeni \\
\hline$\ddot{\mathrm{O}}_{13}$ & Kadın & $11-15$ y1l aras 1 & Türkçe öğretmeni \\
\hline$\ddot{\mathrm{O}}_{14}$ & Erkek & $21-25$ y1l arasi & İngilizce öğretmeni \\
\hline$\ddot{\mathrm{O}}_{15}$ & Kadın & $16-20$ y1l arasi & Teknoloji Tasarım öğretmeni \\
\hline$\ddot{\mathrm{O}}_{16}$ & Erkek & $16-20$ y1l arasi & Sosyal Bilgiler öğretmeni \\
\hline$\ddot{\mathrm{O}}_{17}$ & Erkek & $6-10$ y1l arası & Bilişim Teknolojileri öğretmeni \\
\hline$\ddot{\mathrm{O}}_{18}$ & Kadın & $11-15$ y1l arasi & Fen Bilimleri öğretmeni \\
\hline$\ddot{O}_{19}$ & Kadın & $6-10$ y1l aras1 & İngilizce öğretmeni \\
\hline$\ddot{\mathrm{O}}_{20}$ & Erkek & $21-25$ y1l aras1 & Türk Dili ve Edebiyatı öğretmeni \\
\hline$\ddot{\mathrm{O}}_{21}$ & Kadın & $11-15$ y1l arasi & Biyoloji öğretmeni \\
\hline$\ddot{\mathrm{O}}_{22}$ & Erkek & $21-25$ y1l arasi & Matematik öğretmeni \\
\hline$\ddot{\mathrm{O}}_{23}$ & Kadın & $16-20$ y1l arasi & İngilizce öğretmeni \\
\hline$\ddot{\mathrm{O}}_{24}$ & Erkek & $16-20$ y1l arasi & Türkçe öğretmeni \\
\hline$\ddot{\mathrm{O}}_{25}$ & Kadın & $6-10$ y1l arası & Bilişim Teknolojileri öğretmeni \\
\hline$\ddot{\mathrm{O}}_{26}$ & Erkek & $21-25$ y1l arasi & Sinıf öğretmeni \\
\hline$\ddot{\mathrm{O}}_{27}$ & Kadın & $11-15$ y1l arasi & Fen Bilimleri öğretmeni \\
\hline$\ddot{\mathrm{O}}_{28}$ & Erkek & $21-25$ y1l arasi & Teknoloji Tasarım öğretmeni \\
\hline$\ddot{\mathrm{O}}_{29}$ & Kadın & $16-20$ y1l arasi & Sınıf öğretmeni \\
\hline$\ddot{\mathrm{O}}_{30}$ & Erkek & $16-20$ y1l arasi & Din Kültürü ve Ahlak Bilgisi öğretmeni \\
\hline$\ddot{\mathrm{O}}_{31}$ & Kadın & $6-10$ y1l aras1 & Sosyal Bilgiler öğretmeni \\
\hline$\ddot{\mathrm{O}}_{32}$ & Erkek & $21-25$ y1l arasi & Fen Bilimleri öğretmeni \\
\hline
\end{tabular}

Tablo 1 incelendiğinde çalışma grubunda 15 farklı branştan öğretmen yer almaktadır. Öğretmenlerin mesleki kıdemlerine bakıldığında 6'sının 6-10 y1l arası mesleki kıdeme, 7'sinin 11-15 y1l arası mesleki k1deme, 9' unun 16-20 y1l arası mesleki k1deme ve 10'unun 21-25 y1l aras1 mesleki kıdeme sahip oldukları görülmektedir.

\section{Veri Toplama Aracı}

Veri toplama aracı olarak kelime ilişkilendirme testi kullanılmışır. Kavram; bireylerin zihninde anlamlanan, farklı durumlarda farklı olguların değişebilen özelliklerini temsil eden bilgi yapısıdır (Ülgen, 2004). Kavramlar, yapılan sınıflandırmalar sşı̆̆ında hem varlıkların ayırt edilmesine katkı sağlar hem de olay, olgu, durum ve sürece ilişkin bağlantı kurulmasına olanak tanır (Senemoğlu, 2005). Bilişsel gelişim kavram öğrenimi temelinde gerçekleşir. Öğretmenlerin kavramsal olarak eğitsel etkinliği oluşturması, öğretim sürecinde etkililiği arttıracaktır. Öğretmenlerin düşünceleri, inançları, yaptıkları öğrenme türlerini şekillendiren önemli birer unsurdur (Fullan ve Hargreaves, 1991; McKenzie ve Turbill, 1999).

Bilişsel yapı algıları, algılar da eylemleri yönlendirir. Bilişsel yapının iki temel öğesi olan bilgi birimleri ve bilgi birimlerinin organizasyonu; öğrenmede, hatırda tutmada, öğrenilen yeni bilgi ile eski bilgiler arası bağlantı kurmada oldukça önemlidir. Bilindiği üzere bilişsel yapılar algıları, algılar da eylemleri dönüştürme özelliğine sahiptir (Gilbert, Boulter ve Rutherford, 1998a; Gilbert, Boulter ve Rutherford 1998b; Özenç-Uçak ve Olşen- Güzeldere 2006; Shavelson, 1972; Ülgen, 2004).Kelime ilişkilendirme testi ile öğretmenlerin belli bir zaman diliminde bir konuyla ilgili verilen anahtar kavrama ilişkin kelimeler üretmeleri istenir (Bahar, Nartgün, Durmuş ve Bıçak, 2014; Bahar ve Özatll, 2003; Hovardas ve Korfiatis, 2006). KİT’te öncelikle konu ile ilgili temel kavramlar başka bir deyişle anahtar kavramlar belirlenir. Belirlenen temel kavramlarla, konu ile ilgili diğer önemli kelimelerin ilişkilendirilmesine bakılır. Temel kavramlarla ilişkilendirilen kelimelerin bilimselliği, çeşidi, sayısı, anahtar kavramlar ilişkili olup olmama durumuna göre, zihinsel yapının güçlü olup olmadığına karar verilir. Zihinsel yapı güçlü ise konu birey tarafından biliniyor demektir (Çetin, 2010). Araştırmada veri toplama aracı olarak kullanılan kelime ilişkilendirme testini uygulamak için, öğretmenlere tasarım odaklı düşünme anahtar kavram olarak verilmiştir. Tasarım odaklı düşünme eğitim sürecinin başında ve sonunda ön test ve son test şeklinde bu kavram öğretmenlere verilmiştir. Uygulamada anahtar kavram alt altta bir sayfada yazılarak verilmiştir. Örnek bir sayfa düzeni şu şekildedir:

Tasarım Odaklı Düşünme

Tasarım Odaklı Düşünme 
Tasarım Odaklı Düşünme Tasarım Odaklı Düşünme Tasarım Odaklı Düşünme Tasarım Odaklı Düşünme Tasarım Odaklı Düşünme Tasarım Odaklı Düşünme Tasarım Odaklı Düşünme İlgili Cümle:

Kelime ilişkilendirme testinin nasıl uygulanacağı konusunda çalışma grubunda yer alan öğretmenlere gerekli bilgilendirme yapılarak anahtar kavrama ilişkin kelime yazmaları için 30 saniye süre tanınmıştır. Alan yazın incelendiğinde KİT için verilen süre hedef kitlenin yaş düzeylerine göre farkl1lık göstermektedir. Bazı çalışmalarda anahtar kavrama ilişkin kelime üretirken 30 saniye süre verilirken, bazı çalışmalarda 1 dakika süre verilmektedir (Bahar, Johnstone ve Sutcliffe, 1999; Bahar ve Özatl1, 2003; Ercan, Taşdere ve Ercan, 2010). KİT'te anahtar kavram alt altta bir sayfada yazılarak uygulnacak gruba verilir. Bunun nedeni; anahtar kavrama karş1lı üretilen kelimelerden sonra tekrar anahtar kavrama dönülmesinin sağlanmasıdır. Çünkü eğer bu şekilde yazılmazsa yazılan kelimeler anahtar kavram ile değil, kişinin kendi ürettiği kelimelerle ilgili olacaktır. Bu şekilde yol izlenmesi zincirleme cevap riskini önlemektedir (Bahar, Nartgün, Durmuş ve Bıçak, 2014; Bahar ve Özatl1, 2003; Kostova ve Radoynovska, 2008; Nakiboğlu, 2008). Uygulamada öğretmenlerin anahtar kavram ile ilgili cümle yazılması da istenmiştir. Öğretmenlerin anahtar kavramı bilmediği, kavram yanılgısının olup olmadığını tespit edebilmek için KİT formunun altında kavrama yönelik cümle yazmaları istenmiştir (Ercan, Taşdere ve Ercan, 2010; Işıklı, Taşdere ve Göz, 2011; Nartgün, 2006). Öğretmenlerin yazacak olduğu cümleler yadıkları kelimelere göre daha karmaşık ve üst düzey yapıda olacağından cümlenin bilimsel nitelikte olup olmaması, kavram yanılgıları içerip içermediği gibi durumlar da ortaya konabilmektedir.

\section{Verilerin Analizi}

Süreçte öncelikle öğretmenlere tasarım odaklı düşünme anahtar kavramına ilişkin KİT uygulanmış daha sonra öğretmenlere 3 gün (günde 4 saat) olmak üzere 12 saat tasarım odaklı düşünme eğitimi verilmiştir. Bireyin anlamlı öğrenmesinin en önemli unsuru öğrendiği yeni bilgileri eğitim sonunda ortaya koyabilmesidir. Bu bağlamda tasarım odaklı düşünme eğitimi sonrasında öğretmenlere tekrardan KITT uygulanmıştır. KİT aracılığıyla elde edilen kelimelerin analiz süreci için şu adımlar takip edilmiştir:

(1) katılımcı kâğıtlarını numaralandırma,

(2) her kavram için üretilen kelimeleri listeleme,

(3) kelimeleri alfabetik sıraya koyma,

(4) kelimelerin frekanslarını tespit etme,

(5) tüm kavramlar için satırda kelimelerin sütunda kavramların olduğu ortak frekans tablosu oluşturma,

(6) Bahar, Johnstone ve Sutcliffe (1999) tarafindan önerilen kesme aralıklarını ve bu aralıklara dâhil olan kelimeleri tespit etme,

(7) kavram ağlarını çizme,

(8) geçerlik ve güvenirlik çalışmalarını yapma.

Verilerin analizinde ön test ve son test sonuçlarını değerlendirmek amacıyla tasarım odaklı düşünme anahtar kavramına ilişkin tüm cevaplar incelenmiştir. Anahtar kavram için tekrarlanan kelimeler ve frekans tablosu oluşturulmuştur. Frekans tablosu belirlendikten sonra kesme noktası tekniği ile kesme noktaları belirlenmiştir (Bahar, Johnstone ve Sutcliffe, 1999). Kavram ağları ile kesme noktalarında yer alan ilişkilendirilmiş kelimeler bulgular kısmında verilmiştir. Bu bağlamda, anahtar kelime ile ilgili cümleler sahip oldukları özelliklere göre sınıflandırılmış ve analiz edilmiştir:

1.Bilimsel bilgi içeren cümleler

2.Bilimsel olmayan veya yüzeysel bilgi içeren cümleler 
3.Kavram yanılgısı içeren cümleler

4.Cevapsız (boş bırakılan)

Nitel araştırmalarda araştırmanın güven duyulabilirliğini; inandırıcılık (credibility), aktarlabilirlik (transferability), güvenilebilirlik (dependability) ve onaylanabilirlik (confirmability) ölçütleri sağlamaktadır. Araştırmanın doğrulanabilirliğinin sağlanabilmesi noktasında elde edilen verilerin sonuçlarının sistematik şekilde ve açık, net, anlaşılır bir dille ifade edilmesine çalışılmıştır (Lincoln ve Guba, 1985). Araştırmada aktarılabilirlik ölçütünün karşılanması noktasında araştırmaya katılan öğretmenlerin görüşlerini ortaya çıkarmak amacıyla doğrudan alıntılardan yararlanılmıştır (Yıldırım ve Şimşek, 2011). Araştırmanın bulgular bölümünde de ilgili cümleler için doğrudan alıntılara yer verilmiştir ve her alıntı öğretmenlerin kodlarına göre $\left(\ddot{\mathrm{O}}_{1}\right), \ldots .\left(\mathrm{O}_{32}\right)$ şeklinde temsil edilmiştir Çalışmada her temaya ilişkin kodlama işleminden sonra belirlenen kodlar birbirinden bağımsız iki uzmanın görüşüne sunulmuştur. Araştırmacı ve uzmanlar arasındaki görüş birliği ve ayrılıklarının, araştırmanın güvenirliği üzerindeki etkisi Miles ve Huberman'ın (2015) formülünden [Görüş birliği/(Görüş birliği+Görüş ayrılığı)x100] yararlanılarak yapılmış ve bu inceleme sonucunda araştırmacı ve iki uzmanın görüşleri arasındaki uzlaşma (güvenirlik) \%91 ve \%93 olarak bulunmuştur.

\section{Bulgular}

Araştırmada belirlenen anahtar kavrama yönelik ön testte ve son testte üretilen sözcüklere ilişkin frekans tablosu oluşturulmuştur. Anahtar kavrama ilişkin üretilen sözcüklerin sayıları Tablo 2'de sunulmuştur.

Tablo 2

Anahtar Kavram ve Üretilen Kelimelerin Sayıs

\begin{tabular}{ccccc}
\hline Anahtar kavram & \multicolumn{2}{c}{ Kelime sayısı } & \multicolumn{2}{c}{ Cümle sayısı } \\
\cline { 2 - 5 } & Ön test & Son test & Ön test & Son test \\
Tasarım odaklı düşünme & 63 & 79 & 37 & 49 \\
\hline
\end{tabular}

Tablo 2'de görüldüğü gibi tasarım odaklı düşünme eğitimi öncesi uygulanan KİT'de öğretmenler 63 kelime üretirken, eğitim sonrası uygulanan KİT'de 79 kelime üretmiştir. Son testte anahtar kavrama yönelik üretilen kelime sayısı artış göstermiştir. Bu çerçevede anahtar kavram olan tasarım odaklı düşünme konusunda öğretmenlerin bilişsel yapılarının zenginleştiği ifade edilebilir. Anahtar kavram olan tasarım odaklı düşünmeye ilişkin üretilen kelimeler ile ilgili öğretmenlerin ön test sonucunda bilişsel yapılarını gösteren kavram ağları aşağıda verilmiştir.

\section{Öğretmenlerin Ön Test Sonucunda Bilişsel Yapılarını Gösteren Kavram Ağları}



Kesme noktası 20 ve yukarıs 


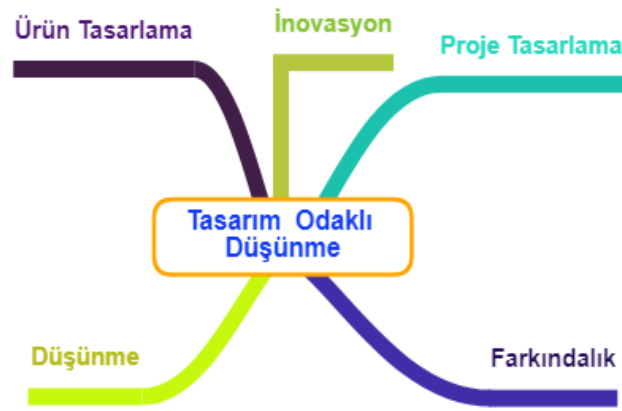

Kesme noktası 15-19

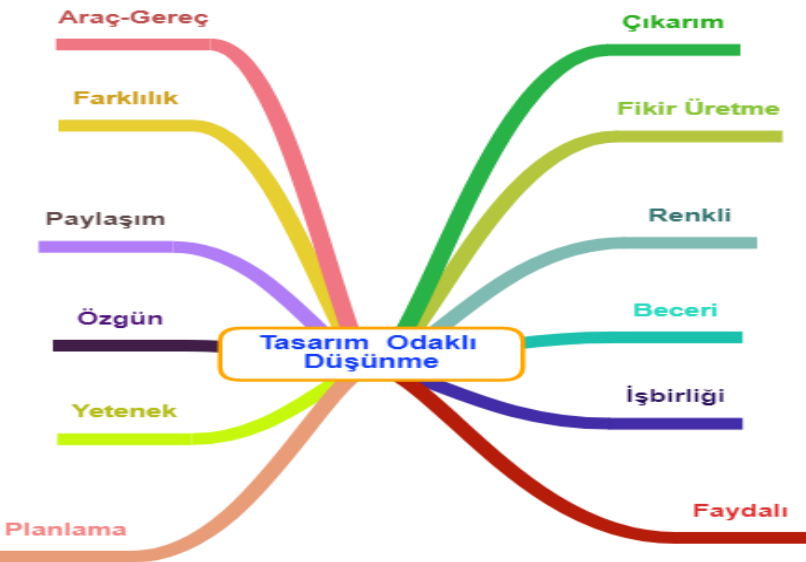

Kesme noktası 10-14

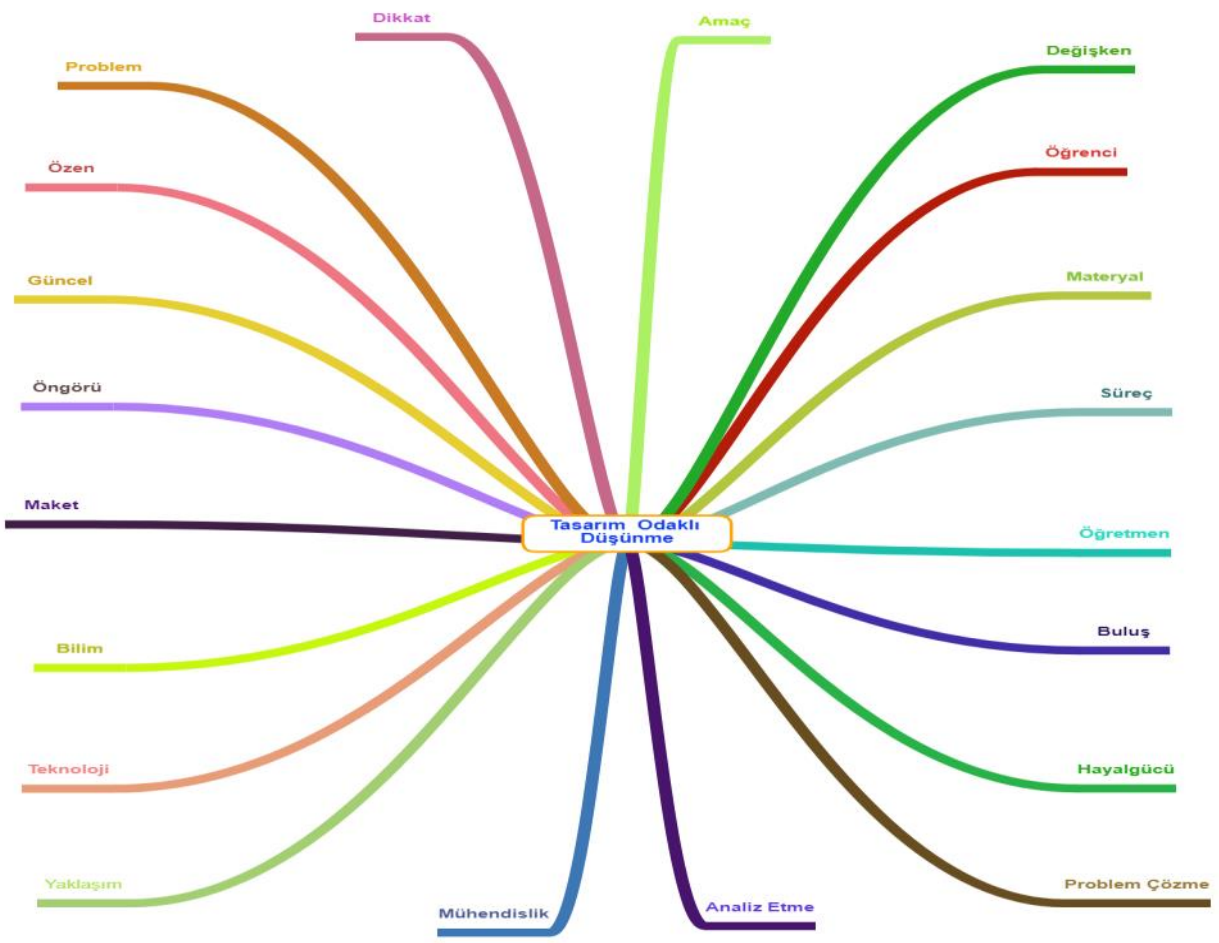

Kesme noktası 5-9 


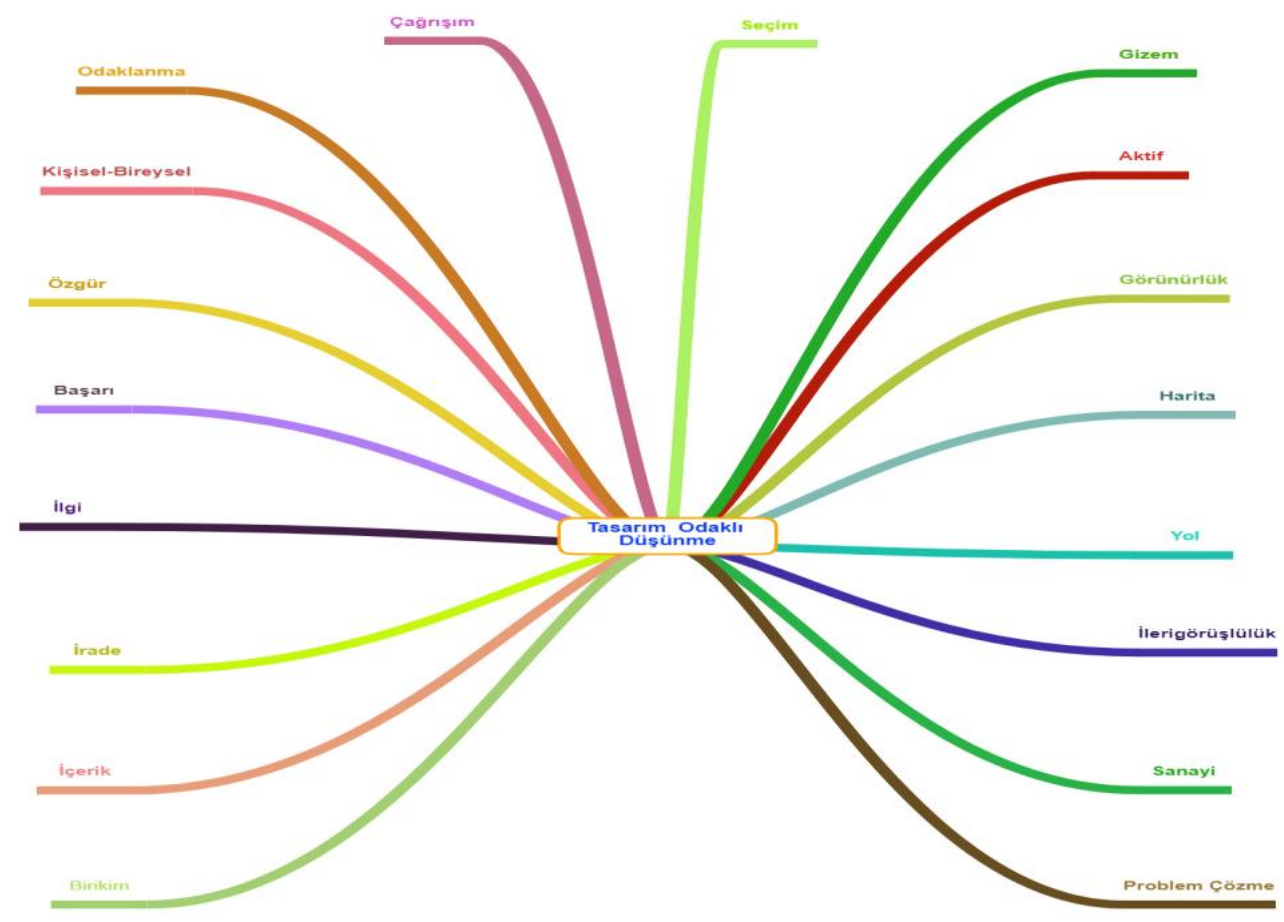

Kesme noktası 1-4

Kesme Noktası 20 ve Yukarısı: Bu kısımda tasarım odaklı düşünme ile yaratıcıllk, yenilik, ürün ve tasarım ilişkilendirmeleri ortaya çıkmıştır. Kesme noktası 20 ve yukarısı için daha çok tasarım odaklı düşünme yapısının temel özellikleri ile ilgili kelimeler üretilmiştir.

Kesme noktası 15-19 arası: $\mathrm{Bu}$ aralıkta ürün tasarlama, proje, tasarlama, düşünme, inovasyon ve farkındalık kelimeleri anahtar kavram ile ilgili olarak üretilmiştir.

Kesme Noktası 10-14 arası: Kesme noktası 10-14 arası için anahtar kavramla ilişkili kelimelerin sayısında artış gözlenmektedir. Bu aralıkta üretilen kelimeler daha çok tasarım odaklı düşünme sürecine yöneliktir.

Kesme Noktası 5-9 arası: Bu aralıkta anahtar kavrama ilişkin üretilen cevap kelimelerde önemli bir artı̧̧ görülmektedir.

Kesme Noktası 1-4 arası: Kesme noktası 1-4 arası için anahtar kavrama ait birçok kelime üretilmiştir. Üretilen bu kelimelerden bazıları anahtar kavram ile ilişkili iken bazıları anahtar kavrama ilişkin kavram yanılgılarını beraberinde getirmiştir. 


\section{Öğretmenlerin Son Test Sonucunda Bilişsel Yapılarını Gösteren Kavram Ağları}

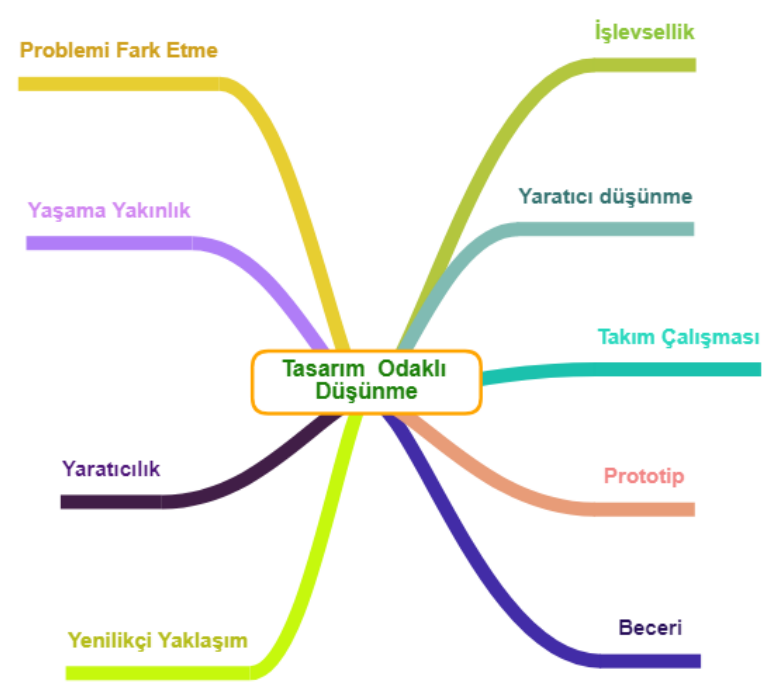

Kesme noktast 20 ve yukarist

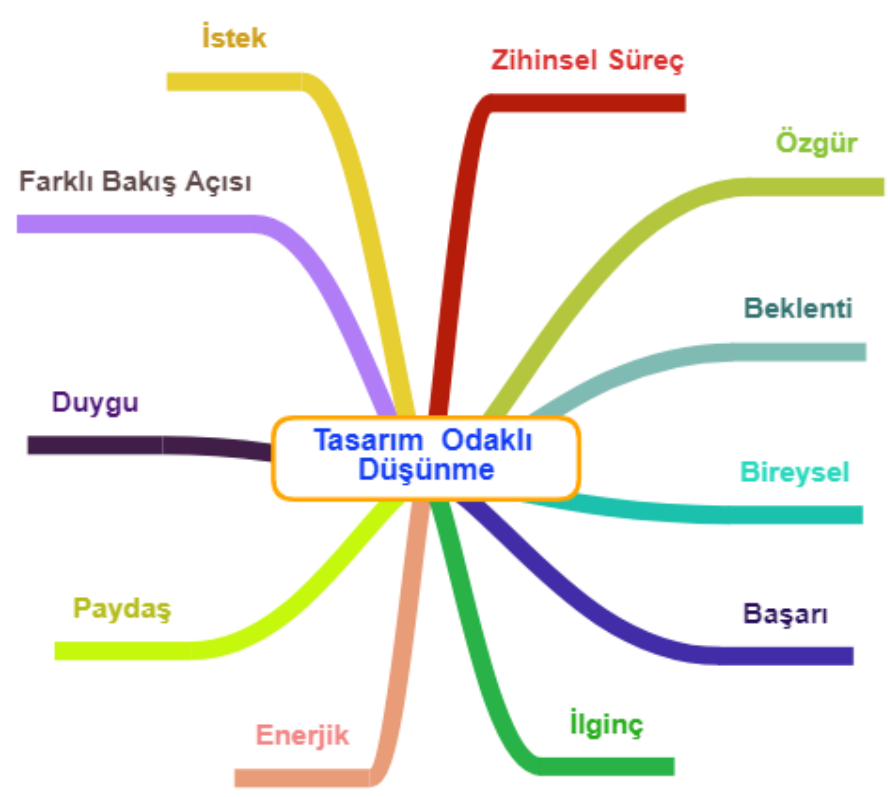

Kesme noktası 15-19 


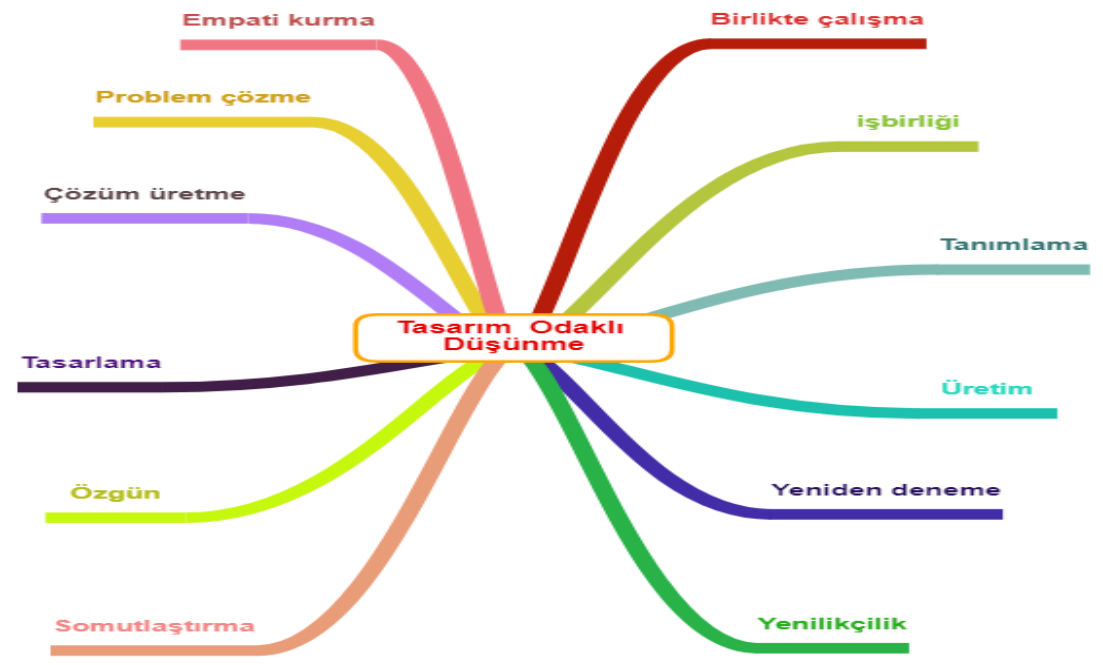

Kesme noktası 10-14

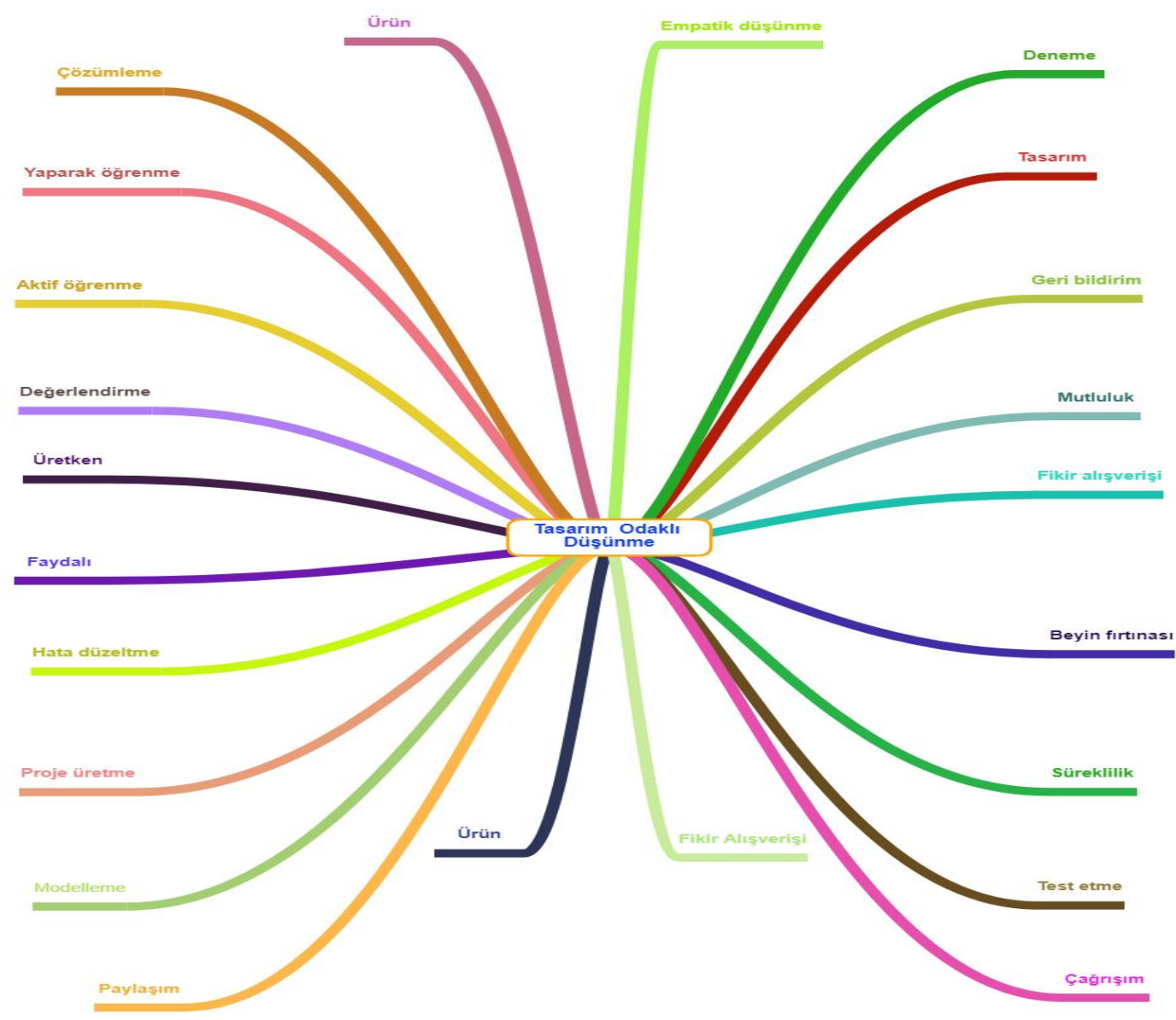

Kesme noktası 5-9 


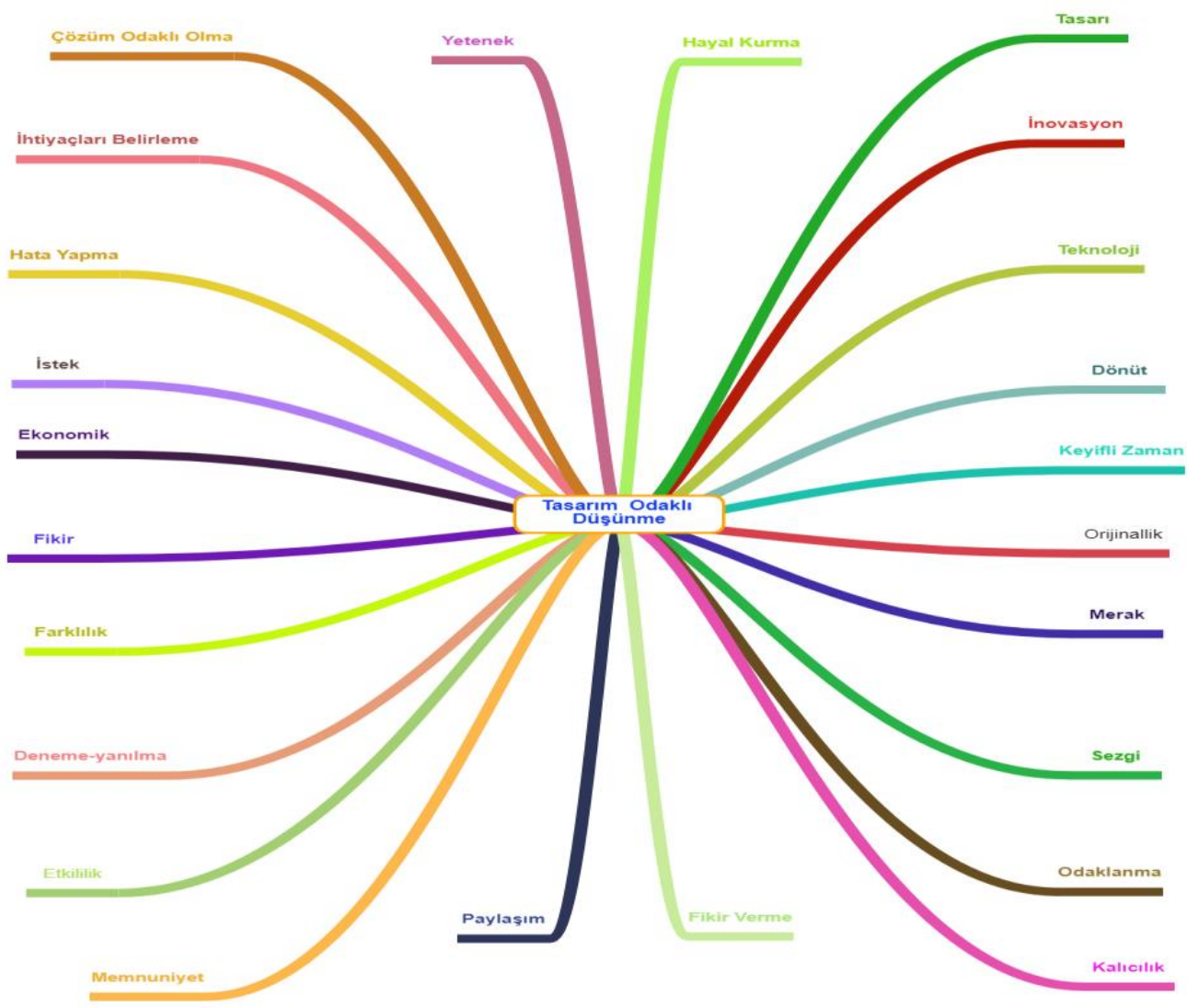

Kesme noktası 1-4

Kesme Noktası 20 ve Yukarısı: Bu aralıkta tasarım odaklı düşünme ile problemi fark etme, takım çalışması, işlevsellik, yaratıcı düşünme, prototip, hayatilik, beceri, yenilikçi yaklaşım ve yaratıcılık ilişkilendirmeleri ortaya çıkmıştır. Kesme noktası 20 ve yukarısı için tasarım odaklı düşünme yapısının temel özellikleri ile ilgili kelimeler üretilmiştir.

Kesme noktası 15-19 arası: Bu aralıkta tasarım odaklı düşünme sürecine yönelik anahtar kavram ile ilgili olarak üretilmiştir. Bu aralıkta anahtar kavram ile ilişkili kelimelerin saysının çok fazla olmasa da arttı̆g görülmektedir.

Kesme Noktası 10-14 arası: Kesme noktası 10-14 arası için anahtar kavramla ilişkili kelimelerin sayısında ciddi bir artış gözlenmektedir. Bu aralıkta üretilen kelimeler daha çok tasarım odaklı düşünme sürecine ve tasarım odaklı düşünme bileşenlerine yöneliktir.

Kesme Noktası 5-9 arası: Bu aralıkta anahtar kavrama ilişkin üretilen cevap kelimelerde artış görülmektedir.

Kesme Noktası 1-4 arası: Kesme noktası 1-4 arası için anahtar kavrama ait birçok kelime üretilmiştir. Üretilen bu kelimeler tasarım odaklı düşünme yapısının tüm bileşenlerini içermektedir. Tasarım odaklı düşünmeye ilişkin farklı kelimeler üretilerek zengin bir kavram ağı yapısı ortaya çıkmıştır.

\section{Öğretmenlerin Ön Test ve Son Test Kavram Ağlarına Göre Bilişsel Yapıların Karşılaştırılması}

- Kesme noktası 20 ve yukarısı için öğretmenlerin ön testte bilişsel yapılarında tasarım odaklı düşünmeye ilişkin birbirinden kopuk kelimeler üretilmiştir. Son testte ise tasarım odaklı düşünme ile birbirine bağlantılı kelimeler üretilmiştir.

- Kesme noktası 15-19 arasında ön testte ürün tasarlama üzerinden bağlantı kurulurken, son testte ise tasarım odaklı düşünme sürecine ilişkin olarak empati kurma, sorunu tanımlama, problem çözme, yeniden deneme gibi kelimeler üretilmiştir.

- Kesme noktası 10-14 arasında anahtar kavramla ilişkilendirilen kelime sayısında son testte artış olmakla birlikte kavramsal ağ yapısında önemli ölçüde bir değişiklik olmamıştır. 
- Kesme noktası 5-9 arasında ön testte anahtar kavram ile birbiri ile ilişkisiz kelimeler üretilse de, son testte tasarım odaklı düşünme kavramına ilişkin uygulama aşamasındaki aktif öğrenme yaklaşımı, yapılan beyin firtınaları, fikir alışverişi, yaparak yaşayarak deneyerek öğrenmenin üzerinde durulmuştur. Bunun yanı sıra duyuşşsal anlamda hayal etme ve mutluluk kelimeleri de üretilmiştir.

- Kesme noktası 4-1 arasında son teste kavram ağının daha ilişkili yapıda olduğu görülmektedir. Bunun yanı sıra tasarım odaklı düşünme kavramı ile ilişkilendirilen kelimelerin sayısında son test lehinde önemli bir artış görülmektedir.

Çalışmada öğretmenlerin anahtar kavram ile ilgili kurdukları cümleler de incelenmiștir. Bu cümleler incelenmiş ve uygun bir şekilde sınıflandırılmıştır. Öğretmenlerin anahtar kavram için yazmış oldukları cümleler bilimsel bilgi ve kavram yanılgısı içerip içermeme durumlarına göre sınıflandırılmıştır. Öğretmenlerin boş bıraktıkları, hiç cümle yazmadıkları, ilgisiz ya da anlaşıır olmayan cevapları da cevapsız kategorisinde ele alınarak sınıflandırılmıştır. Bu bağlamda anahtar kavrama ilişkin öğretmenlerin kurdukları cümleler öne test ve son testte frekansları ile örnek cümleleri içeren halleri ile tablolar halinde verilmiştir.

Tablo 3

Anahtar Kavrama İlişkin Öğretmenlerin Kurduğu İlgili Cümlelerin Ön Test Frekans Tablosu

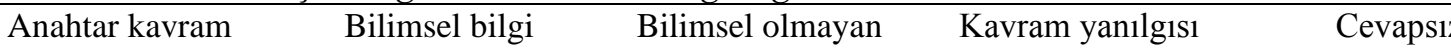
içeren cümle sayısı veya yüzeysel bilgi içeren cümle sayısı içeren cümle sayısı

$\begin{array}{lllll}\text { Tasarım Odaklı } & 11 & 9 & 5 & 4\end{array}$

Düșünme

Tablo 3 incelendiğinde anahtar kavrama ilişkin öğretmenlerin kurdukları cümlelerin 11 ' $\mathrm{i}$ bilimsel bilgi içeren cümle, 9'u bilimsel olmayan veya yüzeysel bilgi içeren cümle, 5'i de kavram yanılgısı içeren cümle olarak ortaya çıkmaktadır. Öğretmenlerin 4'ünün anahtar kavramla ilgili olmayan ya da hiç cevap yazmadıkları görülmektedir.

Tablo 4 Anahtar Kavrama İlişkin Öğretmenlerin Kurduğu İlgili Cümlelerin Son Test Frekans Tablosu

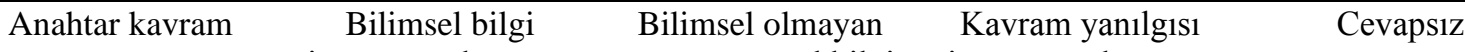
içeren cümle sayısı veya yüzeysel bilgi içeren cümle sayısı içeren cümle sayısı

$\begin{array}{lllll}\text { Tasarım Odakl1 } & 24 & 5 & 2 & 2\end{array}$

Düşünme

Tablo 4 incelendiğinde anahtar kavrama ilişkin öğretmenlerin kurdukları cümlelerin 24'ü bilimsel bilgi içeren cümle, 5'i bilimsel olmayan veya yüzeysel bilgi içeren cümle, 2'si de kavram yanılgısı içeren cümle olarak ortaya çıkmaktadır. Öğretmenlerin 2'sinin anahtar kavramla ilgili olmayan ya da hiç cevap yazmadıkları görülmektedir.

Tablo 3'de ön test ve Tablo 4'de son testlerde anahtar kavram olan tasarım odaklı düşünmeye ilişkin kurulan cümleler incelediğinde kavramsal değişim noktasında olumlu anlamda değişim gösterdiği görülmektedir. Bununla birlikte tasarım odaklı düşünme eğitimi sonrasında uygulanan son testte anahtar kavramla ilgili bilimsel bilgi içeren cümlelerin sayısında artı̧̧ söz konusudur. Ayrıca son testte bilimsel olmayan ve yüzeysel bilgi içeren cümlelerin sayısında da azalma vardır. Kavram yanılgılarının sayısı ön testten son testte doğru da azalmaktadır.

Öğretmenlerin frekans tablolarında cevapsız olarak nitelendirilen kısım öğretmenlerin tasarım odaklı düşünme kavramına ilişkin kavram düzeyinde öğrenemediğini ya da ortaya koyamadığını gösteren bir bulgu olarak ifade edilebilir. Tasarım odaklı düşünmeye ilişkin öğretmenlerin kurmuş oldukları cümleler irdelendiğinde öğretmenlerin bilimsel bilgi içeren cümelerinin arttığı, kavram yanılgılarının azaldığı bir kavramsal değişim süreci yaşadıkları görülmektedir. 
Tablo 5

Ön Test Verilerine Göre Anahtar Kavram ile Illgili Cümle Örnekleri

\begin{tabular}{|c|c|c|c|}
\hline Anahtar kavram & $\begin{array}{l}\text { Bilimsel bilgi içeren cümle } \\
\text { örnekleri }\end{array}$ & $\begin{array}{l}\text { Bilimsel olmayan veya } \\
\text { yüzeysel bilgi içeren } \\
\text { cümle örnekleri }\end{array}$ & $\begin{array}{l}\text { Kavram yanılgısı } \\
\text { içeren cümle örnekleri }\end{array}$ \\
\hline $\begin{array}{l}\text { Tasarım Odaklı } \\
\text { Düşünme }\end{array}$ & $\begin{array}{l}\text { *Planlı bir şekilde } \\
\text { probleme ilişkin somut } \\
\text { ürün oluşturmadır. }\left(\ddot{O}_{2}\right) \\
\text { *Öğrencilerin problem } \\
\text { çözme yönelik ürün } \\
\text { oluşturmasıdır. }\left(\ddot{O}_{22}\right) \\
\text { *Tasarım odaklı ögrrenme } \\
\text { ortamlarında çocuklar çok } \\
\text { yönlü gelişir ve ögrenirler. } \\
\left(\ddot{O}_{13}\right)\end{array}$ & 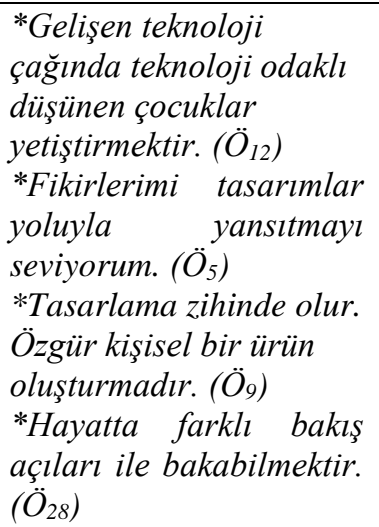 & $\begin{array}{l}\text { *Teknoloji tasarım } \\
\text { dersi ile ilgilidir. }\left(\ddot{O}_{1}\right) \\
\text { *Teknolojik olarak } \\
\text { tasarlamadır. }\left(\ddot{O}_{6}\right) \\
\text { *Daha çok kes- } \\
\text { yapıştır, modelleme } \\
\text { süreçlerini içerir. }\left(\ddot{O}_{17}\right)\end{array}$ \\
\hline
\end{tabular}

Tablo 5 incelendiğinde öğretmenlerin anahtar kavram olan tasarım odaklı düşünmeye ilişkin teknoloji tasarım dersi ile ilişkilendirme yaparak, daha çok kes -yapıştır etkinliklerini olduğunu ifade ettikleri kavram yanılgıları görülmektedir. Bununla birlikte öğretmenler ön test verilerinde tasarım odaklı düşünmenin planl1, sistematik süreçte ürün oluşturulduğunu ortaya koyan bilimsel bilgi içeren cümleler ortaya koymuşlardır.

Tablo 6

Son Test Verilerine Göre Anahtar Kavram ile İlgili Cümle Örnekleri

Anahtar kavram Bilimsel bilgi içeren cümle örnekleri
*Deneme yanilma

problemleri çözebilecek

örnek oluşturmadir. $\left(\ddot{O}_{21}\right)$

*Yaşayarak yaparak ve

Tasarım Odaklt Düşünme sorunlara çözüm üreten

sürece dayalı tasarımsal

düşünebilme, süreci

planlamadir. $\left(\ddot{O}_{4}\right)$

*Empati ile problemlere

yaklassip uygun fikirleri test

edebilmeye imkânı

tanımaktır. $\left(\ddot{O}_{14}\right)$

*Problemleri empatik

düşünerek fikir üretip

problemleri çözebilecek

örnek oluşturmadir. $\left(\ddot{O}_{26}\right)$

*Empati kurarak bir

sorunun çözümüne yönelik

paydaşlart mutlu edecek çözüm önerilerini düşünüp
Bilimsel olmayan veya yüzeysel bilgi içeren cümle örnekleri

*Özgün olmalıyız

tasarlamallyız. $\left(\ddot{O}_{23}\right)$

şansı verilirse kişi en doğruyu bulur. $\left(\ddot{O}_{29}\right)$

*Herkesin

mutlu

Kavram yanılgisı içeren cümle örnekleri

olduğu bir eğitim sistemi yaklaşımıdır. $\left(\ddot{O}_{18}\right)$

*Tasarım odaklı
düşünme daha çok
teknoloji tasarım
dersinde kullanılır.
$\left(\ddot{O}_{11}\right)$

$$
\left(\ddot{O}_{11}\right)
$$




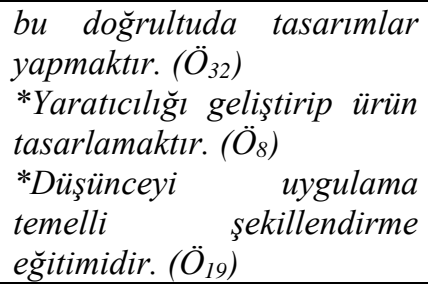

Tablo 6 incelendiğinde öğretmenlerin anahtar kavram olan tasarım odaklı düşünmeye ilişkin kavram yanılgıları azalmaktadır. Bununla birlikte öğretmenler son test verilerinde tasarım odaklı düşünmenin aşamalarını, içeriğini, katkılarını ortaya koyacak birçok bilimsel bilgi içeren cümleler ortaya koymuşlardır.

Öğretmenlerin anahtar kavramla ilişkili kurdukları örnek cümleler incelediğinde, bilimsel bilgi içeren cümlelerin ön testte de olduğu ama son testte çok daha kapsamlı şekilde yer aldığ görülmektedir. Bilimsel olmayan ve yüzeysel bilgi içeren cümlelere bakıldığında son testte frekanslarda azalma olduğu görülmektedir. Kavram yanılgısı içeren cümlelere baktığımızda ön testte çok daha fazla kavram yanılgısı tespit edilirken son testte kavram yanılgıları büyük ölçüde giderilmiş, sadece iki kişide kavram yanılgısı ortaya çıkmıştır. Tasarım odaklı düşünme eğitimi sonucunda son testte de kavram yanılgılarının ortaya çıkmasının nedeni eğitim ile hedeflenen kavramsal değişimin her zaman olumlu yönde ve istenen düzeyde gerçekleşemeyeceğinin göstergesidir.

\section{Sonuç, Tartışma ve Öneriler}

Öğretmenlerin bilişsel yapılarını tespit etmede, kavramsal değişim sürecini ortaya çıkarmada alternatif değerlendirme yaklaşımlarından biri olan kelime ilişkilendirme testleri kullanılmıştır. Değişen eğitim paradigmaları ile öğrenen öğretmen misyonu ile daha kalıc1, etkili, nitelikli öğrenmenin nasıl ölçülüp, değerlendirileceği büyük önem kazanmıştır. 2023 Eğitim Vizyon belgesinde Tasarım-Beceri Atölyeleri ile tasarım odaklı düşünme yapısının bir temel beceri ile hayata geçirilmesi vurgulanmaktadır (MEB, 2018).

21. yüzyıl becerilerinin odağında yer alan yaratıcı düşünme, işbirliği çalışmaları öğrencilerin problem çözme becerilerini geliştiren tasarım odaklı düşünme sistem yapısı ile hayata geçirilmelidir. $\mathrm{Bu}$ bağlamda öğretmenlerin özellikle öğrencilerinin anlamlı öğrenmelerine katkı sağlamaları için birbiri ile ilişkili bilgi yapılarının ölçülmesi ve değerlendirilmesi konusunda bir tanılama aracı olan kelime ilişkilendirme testleri kullanılmıştır. Elde edilen bulgulara göre öğretmenlerin tasarım odaklı düşünme anahtar kavramına ilişkin bilişsel yapısında nelerin olduğu, bunlara ilişkin bağlantıların nasıl kurulduğu ön ve son testle belirlenmiştir. Öğretmenlere tasarım odaklı eğitim öncesinde ve sonrasında uygulanan testler ile bilişsel yapıları ve kavramsal değişimleri hakkında veriler toplanmıştır. Araştırmada öğretmenlerin kavramsal yanılgıları da tespit edilmiştir. Çalışmanın sonuçları irdelendiğinde KİT'in bilişsel yapıyı ve kavramsal değişimi ortaya koymada etkili ve nitelikli bir ölçme değerlendirme yaklaşımı olduğu görülmektedir. Bu araştırmanın sonuçları alan yazında KİT'in etkililiğine ilişkin öğretmenler ve öğretmen adayları ile yapılan farklı birçok çalışma ile de benzerlik göstermektedir (Atabek-Yiğit ve Balkan-Kıyıc1, 2019; Bahar ve Özatlı, 2003; Çetin ve Ünsal, 2019; Gürkan, 2019; Karip, 2019; Kaya ve Bozyiğit, 2018; Nakiboğlu, 2008).

$\mathrm{Bu}$ çalışmada farklı branşlardaki öğretmenlere tasarım odaklı düşünme eğitimi verilmiştir. Araştırma öğretmenlerle 3 gün boyunca (günde 4 saat) gerçekleştirilen toplam 12 saat tasarım odaklı düşünme eğitimi ile sınırlı olup, eğitim öncesinde ve sonrasında bilişsel yapılarındaki farklılık ortaya konmaya çalışılmıştır. Öğretmenlerin eğitim sonundaki anahtar kavrama yönelik kelime ilişkilendirme sonuçlarında artış olduğu gözlenmiştir. Bu bağlamda öğretmenlerin eğitim sonunda derslerde öğrencilerine tasarım düşüncesi yaklaşımını nasıl uygulayacaklarını, tasarım odaklı düşünme aşamalarını, sürecini ve tasarım mantığını öğrendikleri kavramlarla ortaya konmuştur. Öğretmenler tasarım düşüncesinin olumlu anlamda duygulara yönelik katkılarını da belirtmiştir. Alan yazında da tasarım odaklı düşünme yaklaşımının öğrencilerin problem çözme, yaratıcı düşünme ve işbirliği içinde çalışmalarına olumlu katkı sağladığı yapılan çalışmalarla ortaya konmuştur (Anderson, 2012; Scheer 
ve Plattner 2011; Skaggs, Fry ve Howell 2009; Watson, 2015). Öğretmenler son teste anahtar kavrama ilişkin keyifli zaman, istek ve memnuniyet kavramlarını belirtmişlerdir. Tasarım düşüncesinin yapılandırmacı bir öğrenme stratejisi olarak öğrencinin motive edilmesini sağladığı alan yazında ortaya konmuştur (Bruton, 2010; Carrol, 2014; Scheer ve Plattner, 2011).

Düşünmeyi ve öğrenmeyi tasarlamak için bütüncül bir yaklaşım olan tasarım düşüncesi, gerçek hayat problemlerine yönelik yaratıcı bir şekilde problem çözme ve disiplinler arası takımlarda başarılı şekilde çalışmayı sağlamaktadır (Rauth, Köppen, Jobst ve Meinel, 2010). Carroll vd. (2010) ortaokul öğrencileri ile gerçekleştirdikleri araştırmada tasarım düşüncesi ile öğrencilerin yaratıcı şekilde sürece katıldıklarını, yenilikçi düşünme sistemlerini teşvik ettiğini tespit etmiştir. Tasarım düşüncesinin problem çözme yaklaşımında, girişimcilik, inovasyon çalışmaları, sosyal yardım gibi farklı alanlarda ve disiplinlerde uygulanabilen bir yapı olarak güçlü, etkili ve geniş ölçüde anlamlı etki yaratan düşünme olduğu belirtilmiştir (Beckman ve Barry, 2007; Kimbell, 2011) Geleneksel öğrenme yaklaşımlarının aksine, tasarım düşüncesi dinamik ve doğrusal olmayan yapısı ile öğrenenlerde olumlu düşünmeyi arttırarak başarısızlık korkusunu ortadan kaldırmaktadır (Carrol, 2014; Kimbell, 2011). Tasarım düşüncesi ile yaratıcı düşünmenin rolü, tasarım odaklı düşünme ile yaratıcı düşünme yolları öğretmenler tarafından öğrencilere kazandırılması gereken önemli noktalar olarak belirtilmiştir (Melles, Howard ve Thompson-Whiteside, 2012).

Çalışma sonucunda KİT'in öğretmenlerin tasarım odaklı düşünmeye ilişkin kavramsal yapıyı ortaya koymada ve kavramsal değişimi belirlemede uygulanabilecek önemli bir yaklaşım olabileceği sonucuna ulaşılmıştır. KİT ile öğretmenlerin sadece tasarım odaklı düşünme kavramına ilişkin hatırlama düzeyinde çağrışım yapan kelimeleri incelenmemiş ayrıca öğretmenlerin anahtar kavrama yöenlik kavram yanılgısının olup olmadığını ve bilimsel bilgiye sahip olup olmadığını tespit edebilmek içinde cümle yazmaları istenmiştir. Böylelikle anahtar kavrama ilişkin yazılan cümleler bilimsel bilgi, kavram yanılgıları gibi durumlar bakımından da değerlendirilmiştir. Çalışmada öğretmenlerin yazmış oldukları cümleler incelendiğinde son testte bilimsel bilgi içeren cümlelerin arttığ1, kavram yanılgısı içeren cümlelerin azaldığı görülmüştür. Araştırmada elde edilen sonuçlara dayalı olarak şu öneriler getirilebilir:

- Öğretmenlerin kavramsal değişimlerini ortaya koyacak daha uzun süreli tasarım odaklı eğitim içeriği planlanarak, süreç öncesi ve sonrasındaki fark ortaya konulabilir.

- Öğretmenler alternatif ölçme-değerlendirme tekniği olan KİT’in kullanılması bağlamında teşvik edilebilir. $\mathrm{Bu}$ noktada öğretmenlere hizmet-içi eğitimler verilerek yeterlilikleri geliştirilebilir.

- Hizmet öncesinde öğretmen adayları tasarım odaklı düşünme konusunda donanımlı yetiştirilmeli, bu düşünce yapısını 21.yy temel becerileri kapsamında benimsemelidir. $\mathrm{Bu}$ bağlamda öğretmen adaylarına tasarım odaklı düşünme ile ilgili farkındalık eğitimleri verilebilir. Tasarım odaklı düşünmeye ilişkin öğretmen adaylarının bilişsel yapıları ve kavramsal değişimleri kelime ilişkilendirme testleri incelenebilir.

Açıklamalar: Bu çalışmadaki uygulama 4-6 Ekim 2018 tarihinde TÜBİTAK 4007 Bilim Şenlikleri Destekleme Programı kapsamında Rize Bilim Şenliği-2 projesinde Tasarım Odaklı Düşünüyorum ve Projelendiriyorum isimli atölyede gerçekleştirilmiştir. 


\section{Kaynaklar}

Anderson, N. (2012). Design thinking: Employing an effective multidisciplinary pedagogical framework to foster creativity and innovation in rural and remote education. Australian and International Journal of Rural Education, 22(2), 43-52.

Atabek-Yiğit, E. ve Balkan-Kıyıcı, F. (2019). Öğretmen adaylarının öğretmen algısı. Muğla Sitkı Koçman Üniversitesi Eğitim Fakültesi Dergisi [MSKU Journal of Education], 6(1), 2039.Bahar, M., Alex H., Johnstone ve Sutcliffe, R. (1999). Investigation of students' cognitive structure in elementary genetics through word association tests. Journal of Biological Education, 33, 134.

Bahar, M., Johnstone, A. H. ve Sutcliffe, F. G. (1999). Investigation of students' cognitive structure in elementary genetics through word association tests. Journal of Biological Education, 33(3), 134-141.

Bahar, M., Nartgün, Z., Durmuş, S. ve Bıçak, B. (2014). Geleneksel-tamamlayıcı ölçme ve değerlendirme teknikleri: Öğretmen el kitabı. Ankara: Pegem Akademi.

Bahar, M., ve Özatlı, N.S. (2003). Kelime ilişkilendirme yöntemi ile lise 1. sinıf öğrencilerinin canlıların temel bileşenleri konusundaki bilişsel yapılarının araştırılması. Balıkesir Üniversitesi Fen Bilimleri Dergisi, 5(1),75-85.

Bahar, M. and Tongaç, E. (2009). The effect of teaching approaches on the pattern of pupils' cognitive structure: Some evidence from the field. Asia-Pacific Education Researcher, 18,(1), 21-45.

Barseghian, E. (2010). Design thinking sparks learning in rural North Carolina. 14 Nisan 2019 tarihinde http://blogs.kqed.org/mindshift/2010/11/design-thinking-sparks-learning-in-rural-ncarolina/_adresinden erişilmiştir.

Beckman, S. L. and Barry, M. (2007). Innovation as a learning process: Embedding design thinking. California Management Review, 50(1).

Bootcamp Bootleg D.School (2011). Bootcamp bootleg, hassno platner \& institute of design at stanford university (online). $4 \quad$ Nisan 2019 tarihinde https://dschool.stanford.edu/s/METHODCARDS-v3-slim.pdf adresinden erişilmiştir.

Brown, T. (2008). Design thinking. Harvard business review. 21 May1s 2019 tarihinde https://www.scopus.com/record/display.uri?eid=2-s2.0-80052253102\&origin=inward adresinden erişilmiştir.

Brown, T. (2009). Change by design: How design thinking transforms organizations and inspires innovation. New York: HarperCollins.

Bruton, A. (2010). Teaching and learning for the 21 st century. In international council for small business. International Conference. Cincinnati, Ohio: ICSB.

Büyüköztürk, Ş., Çakmak E., Akgün, Ö. E., Karadeniz, Ş. ve Demirel, F. (2014). Bilimsel araştırma yöntemleri (18. Baskı). Ankara: Pegem Yayıncılık.

Carroll, M., Goldman, S., Britos, L., Koh, J., Royalty, A. and Hornstein, M. (2010). Destination, imagination and the fires within: Design thinking in a middle school classroom. International Journal of Art and Design Education, 29(1), 37-53. 
Carrol, M. P. (2014). Shoot for the moon! The mentors and the middle schoolers explore the intersection of design thinking and STEM. Journal of Pre-College Engineering Education Research (J-PEER), 4(1).

Çetin, A. (2010). Fen ve teknoloji dersinde işbirlikli öğrenme tekniklerinin öğrencilerin başarı, tutum ve zihinsel yapılarına etkisi. Yüksek Lisans Tezi, Sosyal Bilimler Enstitüsü, Mustafa Kemal Üniversitesi, Hatay.

Çetin, A. ve Ünsal, S. (2019). Öğretmen adaylarının değerlerle ilgili zihinsel yapıları. Mehmet Akif Ersoy Üniversitesi Ĕ̈itim Fakültesi, 49, 187-210.

Davis, M. (1998). Making a case for design-based learning. Arts Education Policy Review, 100 (2), 7 15.

Deese, J. (1962). Form class and determinants of association. Journal of Verbal Learning and Verbal Behavior, 2, 79 - 84.

Dukes, C. ve Koch, K. (2012). Crafting a delightful experience: teaching interaction design to teens. Interactions, 19 ( 2), 46-50.

Ercan, F., Taşdere, A. ve Ercan, N. (2010). Kelime ilişkilendirme testi aracılığıyla bilişsel yapının ve kavramsal değişimin gözlenmesi. Türk Fen Eğitimi Dergisi, 7 (2), 136-154.

Fraenkel. J. R. and Wallen. N.E. (2006). How to design and evaluatere search in education. New York: McGraw-Hill.

Fullan, M. and Hargreaves, A. (1991). What is worth fighting for in your school. New York: Teachers College Press.

Gilbert, J. K., Boulter,C. and Rutherford, M. (1998a). Models in explanations, part 1, horses for courses?. International Journal of Science Education, 20, 83-97.

Gilbert, J.K., Boulter,C. and Rutherford, M. (1998b). Models in explanations, part 2, whose voice?whose ears?. International Journal of Science Education, 20, 187-203.

Goldman, S., Knudsen, J. and Latvala, M. (1998). Engaging middle schoolers in and through real world mathematics. In L. Leutzinger (Ed.), Mathematics in the middle (pp. 129-140). Reston, VA: National Council of Teachers of Mathematics.

Gürkan, B. (2019). Sınıf öğretmeni adaylarının "eğitim programı, öğretim, öğretimi planlama ve öğretimi değerlendirme" kavramlarına ilişkin bilişsel yapıları. Kastamonu Education Journal, $27(2), 633-645$.

Hovardas, T. and Korfiatis, K. J. (2006). Word associations as a tool for assessing conceptual change in science education. Learning and Instruction, 16, 416-432.

Işıklı, M., Taşdere, A. ve Göz, N. L. (2011). Kelime ilişkilendirme testi aracılığıyla öğretmen adaylarının atatürk ilkelerine yönelik bilişsel yapılarının incelenmesi. Uşak Üniversitesi Sosyal Bilimler Dergisi, 4(1), 50-72.

Kafai, Y. and Resnick, M. (1996). Constructionism in practice: Design thinking, and learning in a digital world. Mahwah, NJ: Lawrence Erlbaum.

Kali, Y., McKenney, S. and Sagy, O. (2015). Teachers as designers of technology enhanced learning. Instructional Science, 43, 173-179. 
Karasar. N. (2012). Bilimsel araştırma yöntemi. Ankara: Nobel Yayın Dağıtım.

Karip, F. (2019). Analyzing the cognitive structures of pre-service teachers who take art education classes related to art concept. Universal Journal of Educational Research 7(1), 178-189.

Kaya, B. ve Akış, A. (2015). Coğrafya öğrencilerinin "hava" kavramıyla ilgili bilişsel yapılarının kelime ilişkilendirme testi ile belirlenmesi. Turkish Studies International Periodical For The Languages, Literature and History of Turkish or Turkic, 10(7), 557-574.

Kaya, B. and Bozyiğit, R. (2019). Considerations of pre-service geography teachers related to the concept of geography. International Journal of Geography and Geography Education, 39, 5569.

Kimbell, L. (2011). Rethinking design thinking: Part I. Design and Culture, 3(3), 285-306.

Kirschner, P. A. (2015). Do we need teachers as designers of technology enhanced learning? Instructional Science, 43, 309-322.

Kolodner, J. L., Camp, P. J., Crismond, D., Fasse, B., Gray, J., Holbrook, J. and Ryan, M. (2003). Promoting deep science learning through case-based reasoning: Rituals and practices in learning by design classrooms. In N. M. Steel (Ed.), Instructional design: International perspectives (p. 89 114). Mahwah, NJ: Lawrence Erlbaum.

Kostova, Z. and Radoynovska, B. (2008). Word association test for studying conceptual structures of teachers and students. Bulgarian Journal of Science and Education Policy, 2(2), 209-231.

Krieger, M. (2010). Introduction to design thinking. 21 May1s 2019 tarihinde http://www.slideshare.net/mileyk/intro-to-design-thinking adresinden erişilmiştir.

Lee, Y. and Bichard, J. A. (2008) Teen-scape: designing participations for the design excluded. Congress proceedings of PDC 2008, Bloomington, USA. Indiana University: ACM, 128-37.

Liedtka, J. (2011). Learning to use design thinking tools for successful innovation. Strategy and Leadership, 39(5), 13-19.

Lincoln, Y. S. and Guba, E. A. (1985). Naturalistic inquiry. Beverly Hills, CA: Sage.

Lockwood, T. (Ed.). (2009). Design thinking: Integrating innovation, customer experience, and brand value. New York, NY: Design Management Institute/Allworth Press.

Löwgren, J. and Stolterman, E. (2004). Thoughtful interaction design: A design perspective on information technology. Cambridge, MA: MIT Press.

Martin, R. (2009). The design of business. Boston, MA: Harvard Business School Press.

Martin, R. (2012). Design thinking: An interview with Martin Roger. Research Technology Management, May-June (pp. 10-14).

Mckenzie, B. and Trubill, J. (1999). Professional development, classroom practice and students out comes: exploring the connecti $\neg$ on in early literacy development. 25 May1s 2019 tarihinde https://files.eric.ed.gov/fulltext/ED447453.pdf adresinden erişilmiştir.

MEB. (2018). 2023 Eğitim Vizyonu. Milli Eğitim Bakanlığı. Ankara 15 Ocak 2019 tarihinde http://2023vizyonu.meb.gov.tr/ adresinden erişilmiştir. 
Meinel, C. and Leifer, L. (2011). Design thinking research. In H. Plattner, C. Meinel, ve L. Leifer (Eds.), Design thinking: Understand improve apply. Heidelberg, Germany: Springer.

Melles, G., Howard, Z. and Thompson-Whiteside, S. (2012). Teaching design thinking: Expanding horizons in design education. In Procedia - Social and Behavioral Sciences 31. Elsevier Ltd. $162-166$.

Miles, M. B. ve Huberman, A. M. (2015). Nitel veri analizi: genişletilmiş bir kaynak kitap. S. Akbaba Altun ve A. Ersoy (Çev. Ed). Ankara: Pegem Akademi.

Nakiboğlu, C. (2008). Using word associations for assessing non major science students' knowledge structure before and after general chemistry instruction: in the case of atomic structure. Chemistry Education Research and Practice, 9, 309-322.

Nartgün, Z. (2006). Fen ve Teknoloji Öğretiminde ölçme ve değerlendirme, M. Bahar (Ed.), Fen ve Teknoloji ögretimi içinde (s. 355-415). Ankara: Pegem Akademi Yayıncılık.

Nussbaum, B. (2009). Latest trends in design and innovation-and why the debate over design thinking is moot. Business Week Online. 21 May1s 2019 tarihinde http://www.businessweek.com/innovate/NussbaumOnDesign/archives/2009/07/latest_trends_i .html adresinden erişilmiştir.

Özata-Yücel, E. and Özkan, M. (2015). Determination of secondary school students' cognitive structure and misconception in ecological concepts through word association test. Educational Research and Reviews, 10(5), 660-674.

Özatlı, N.S. ve Bahar, M. (2010). Öğrencilerin boşaltım sistemi konusundaki bilişsel yapılarının yeni teknikler ile ortaya konması. Abant İzzet Baysal Ünv. Dergisi, 10(2), 9-26.

Özenç-Uçak N. ve Olşen-Güzeldere, Ş. (2006). Bilişsel yapının ve işlemlerin bilgi arama davranış1 üzerine etkisi. Türk Kütüphaneciliği, 20(1), 7-28.

Pendleton-Jullian, A., and Brown, J. S. (2011). Design unbound: Evolving design literacy pathways of efficacy. Draft manuscript, Charleston, SC.

Philloton, E. ve Miller, M. (2011). Design, build, transform. 14 Nisan 2019 tarihinde http://www.studio-h.org/about adresinden erişilmiştir.

Pink, D. H. (2005). A whole new mind: Why right-brainers will rule the future. New York: Riverhead.

Plattner, H. (2010). An introduction to design thinking: Process guide. Stanford, CA: Hasso Plattner Institute of Design at Stanford University.

Polat, G. (2013). 9. sınıf öğrencilerinin çevreye ilişkin bilişsel yapılarının kelime ilişkilendirme test tekniği ile tespiti. Necatibey Eğitim Fakültesi Elektronik Fen ve Matematik Eğitimi Dergisi (EFMED), 7(1) 97-120.

Rauth, I., Köppen, E., Jobst, B. and Meinel, C. (2010). Design thinking: An educational model towards creative confidence. In First International Conference on Design Creativity (pp. 1-8). Kobe, Japan.

Rodgers, P. and E. Winton.( 2010). Design thinking a critical analysis. In proceedings of e\&pde 2010, The 12th International Conference on Engineering and Product Design Education-When Design Education and Design Research Meet, Trondheim, Norway, September 2-3, 2010. 
Scheer, A. and Plattner, H. (2011). Transforming Constructivist Learning into Action: Design Thinking in education. Design and Technology Education: An International Journal, 17(3), 819.

Scheer, A., Noweski, C. and Meinel, C. (2012). Transforming constructivist learning into action: Design thinking in education. Design and Technology Education: An international Journal, 7(3), 819 .

Senemoğlu, N. (2005). Gelişim ögrenme ve ögretim: Kuramdan uygulamaya (12. Bask1). Ankara: Gazi Kitabevi.

Shavelson, R. J. (1972). Some aspects of the correspondence between content structure in physics instruciton. Journal of Educational Psychology, 63(3), 225-234.

Skaggs, P., Fry, R. and Howell, B. (2009). innovations unlimited: Thinking about design thinking. In The NCIIA 13th Annual Meeting (p. 2009). Washington, D.C.

Simon, H. A. (1996). The sciences of the artificial (3rd ed.). Cambridge, MA: The MIT Press.

Svihla, V., Reeve, R., Sagy, O. and Kali, Y. (2015). Supporting teacher designers: A synthesis of how teachers learn as they design, what they learn from design, and how they collaborate during design. Instructional Science, 43, 283-307.

Tan, C. and Wong, Y. (2012). Promoting spiritual ideals through design thinking in public schools. International Journal of Children's Spirituality, 17(1), 25-37.

Taşdere, A., Özsevgeç, T. ve Türkmen, L. (2014). Bilimin doğasına yönelik tamamlayıcı bir ölçme aracı: kelime ilişkilendirme testi. Fen Bilimleri Öğretimi Dergisi, 2(2),129-144.

Todd, R. (1999). Design and technology yields a new paradigm for elementary schooling. Journal of Technology Studies, 25(2), 26-33.

Treffinger, D. J. (1980). Encouraging creative learning for the gifted and talented. Ventura, CA: Ventura County Schools/LTI.

Ülgen, G. (2004). Kavram geliştirme: Kuramlar ve uygulamalar. Ankara: Nobel Yayın Dağıtım.

Vande Zande, R., Warnock, L., Nikoomanesh, B. and Van Dexter, K. (2014). The design process in the art classroom: Building problem-solving skills for life and careers. Art Education, $67(6), 20-27$.

Vaughn, M. and Parsons, S. A. (2013). Teachers as innovators: Instructional adaptations opening spaces for enhanced literacy learning. Language Arts Journal, 91, 81-93.

Watson, A. (2015). Design thinking for life. Art Education,68(3), 12-18.

Yıldırım, A. ve Şimşek, A. (2011). Sosyal bilimlerde nitel araştırma yöntemleri. Ankara: Seçkin Yayınları.

Yiğit, C. and Atabek-Yiğit, E. (2016). Mechanical engineering students' learning styles and their perception of profession. European Journal of Education Studies, 2(12), 121-137. 


\section{Extended Abstract}

\section{Introduction}

Design-based thinking is a learning approach that is focused on developing students' creative confidence. It contains many elements such as developing empathy, encouraging preconceived opinion towards action, guiding thinking principles, improve meta-cognitive awareness, being active, solving problems and being able to use individual creative faculty. Word association test is the most frequently used technique in measuring the cognitive structure and determining the relationship between concepts (Bahar, Nartgün, Durmuş ve Bıçak, 2010). Design-based thinking is called "Design-Skills Workshop" in 2023 Turkey Education Vision document with the aim of creating and constructing the national standards in education (MEB, 2018). In this regard, this study will contribute to the field not only by determining the cognitive structure of teachers in terms of design-based thinking and revealing their conceptual change but also using word association test in presenting such relationship. Within this framework, the aim of this study is to reveal the teachers' cognitive structure towards design-based thinking and their conceptual change through the application of word association test.

\section{Method}

This study is conducted with teachers working in different fields of study and aimed at revealing their cognitive structure and conceptual change concerning education in Design-based thinking by using scanning model. The participants consist of 32 (16 male, 16 female) teachers working in different fields of study at the primary, middle and high schools in the centre of Rize region during the 2018-2019 educational year. As for the data collection, the word association test was used. Regarding the application of the word association test, the necessary information was given to the teachers in the study group and they were given 30 minutes to write words about the key concepts. Teachers were also asked to write sentences about the key concepts. During the implementation process, WAT was applied to teachers initially in relation to the key concept of design-based thinking and then teachers were given an education in design-based thinking for 3 days ( 4 hours per day and 12 hours in total). Then, after their education in design-based thinking WAT was re-applied. In order to evaluate the results of pre-test and post-test all the answers were assessed related to the key concepts in design-based thinking. After establishing the frequency table, 'cut-off points' were determined using 'cut-off point' technique (Bahar, Johnstone ve Sutcliffe, 1999). Concept map and related words located at the cut-off points were given in the result section below. Sentences about the keywords were classified according to their features and analysed. Related sentences are given in direct quotations in the result section of this study and each quotation is represented according to the teachers' code with (Ö1),....(Ö32). The determined codes after the coding process in relation to each theme were presented to the opinions of the two independent experts. The effects of the consensus and disagreements among the researchers and experts on the reliability of the study are calculated using the formula of Miles and Huberman (2015) [consensus/ (consenses+disagreement) x100] and as the result of this study consensus (reliability) between the researcher and two experts was found as \%91 and $\% 93$.

\section{Result}

In the study, while teachers produced 63 words in the WAT, applied before the education in design-based thinking after the education they produced 79 words. In the post-test, there was an increase in the produced words concerning key concepts. Therefore, the results demonstrate that teachers' cognitive structure became richer in terms of design-based thinking which is the key concept. Teachers' sentences related to the key concepts were also assessed in the study. In agreement with the post-tests, when sentences related to the key concept design-based thinking is examined positive changes occurred at the point of conceptual change. Also there was an increase in the sentences with the scientific content related to the key concept in the post-test after the education of design-based thinking. Moreover, the number of sentences with the content of nonscientific and 
superficial information decreased in the post-test and the number of misconceptions decreased from the pre-test to the post-test. It was found that there are more misconceptions in the pre-test, the misconceptions in the post-test mostly eliminated and misconceptions occurred only in two people.

\section{Discussion and Conclusion}

In determining teachers cognitive structure, and revealing their conceptual change an alternative assessment approach, the word association tests were used. Together with the everchanging educational paradigms and teacher-learner mission, measuring and evaluating more permanent, effective, quality learning became more important. In this context, word association tests which are an identifying tool for measuring and evaluating interrelated knowledge structure were used to contribute to teachers' but in particular their students' meaningful learning. According to the results, the content of teachers cognitive structure in relation to the key concept design-based thinking and the way they establish these connections were determined through pre-test and post-test. The results of the study showed that WAT has been an effective and eligible evaluation approach in revealing the cognitive structure and conceptual change. The study has also demonstrated similar results with the many other different studies in the related field that were carried out with teachers and teacher candidates about the effectiveness of WAT (Atabek-Yiğit and Balkan-Kıyıc1, 2019; Bahar and Özatl1, 2003; Çetin and Ünsal, 2019; Gürkan, 2019; Karip, 2019; Kaya and Bozyiğit, 2018; Nakiboğlu, 2008). In relation to the results of this study suggestions such as below may be given:

-It is suggested that different studies may be carried out concerning teachers' and teacher candidates' conceptual understanding and knowledge level in relation to design-based thinking.

- Teachers may be encouraged in using alternative measuring- assessment techniques. At this point, teachers may be given in-service workshops to develop their competency.

- Teachers may be educated before service to be competent in design-based thinking and such a mindset may be implemented within the scope of basic skills of the 21st century. Within this context academicians at the universities should create consciousness in teacher candidates about design-based thinking.

- Teacher candidates' cognitive structures and conceptual change concerning design-based thinking may be analysed through the application of word association tests. 